\title{
Herding, Information Cascades and Volatility Spillovers in Futures Markets*
}

\author{
Michael McAleer \\ Econometric Institute \\ Erasmus School of Economics \\ Erasmus University Rotterdam \\ and \\ Tinbergen Institute \\ The Netherlands \\ and \\ Institute of Economic Research \\ Kyoto University \\ and \\ Department of Quantitative Economics \\ Complutense University of Madrid \\ Kim Radalj \\ Department of Economics, \\ University of Western Australia
}

Revised: June 2013

* The authors are most grateful to Felix Chan for helpful discussions. For financial support, the first author wishes to thank the Australian Research Council, National Science Council, Taiwan, and the Japan Society for the Promotion of Science. The second author wishes to acknowledge the financial assistance of a Hackett Postgraduate Scholarship at the University of Western Australia. 


\begin{abstract}
Economists and financial analysts have begun to recognise the importance of the actions of other agents in the decision-making process. Herding is the deliberate mimicking of the decisions of other agents. Examples of mimicry range from the choice of restaurant, fashion and financial market participants, to academic research. Herding may conjure negative images of irrational agents sheepishly following the actions of others, but such actions can be rational under asymmetric information and uncertainty. This paper uses futures position data in nine different markets of the Commodity Futures Trading Commission (CFTC) to provide a direct test of herding behaviour, namely the extent to which small traders mimic the positions of large speculators. Evidence consistent with herding among small traders is found for the Canadian dollar, British pound, gold, S\&P 500 and Nikkei 225 futures. Consistent with survey-based results on technical analysis, the positions are significantly correlated with both current and past market returns. Using various time-varying volatility models to accommodate conditional heteroskedasticity, the empirical results are found to be robust to alternative models and methods of estimation. When a test of causality-in-variance is used to analyse if volatility among small traders spills over into spot markets, it is found that spillovers occur only with Nikkei 225 futures. The policy implications of the findings are also discussed.
\end{abstract}

Keywords: Herding, speculation, hedging, noise traders, currency and commodity markets, futures and spot markets, time-varying volatility, causality-in-variance, spillovers.

JEL Classification: D82, D84, G12, G14. 


\section{Introduction}

Herding, or the deliberate mimicking of the decisions of other agents after such decisions have been observed, is a widespread social phenomenon. Throughout the animal kingdom, herding is a natural instinct as it provides safety from predators. There is an increasing acceptance of the existence of herding among economic and financial agents. Asch (1952) provided experimental evidence to show that subjects consider the opinions of others in formulating their own decisions. Becker (1991) has argued that herding can occur in a variety of social situations, such as restaurant choice. Individuals often conform as they either have a preference to do so, or numbers reaffirm the decisions made by agents. Although herding tends to conjure images of lemmings mindlessly falling over a cliff, such a conception would be misguided, as herding can be rational at an individual level under appropriate conditions.

The tendency of financial market participants to base their decisions on those of others, rather than on their private information, was apparent to Keynes (1936, p.157): "Investment based on genuine long-term expectations is so difficult ... as to be scarcely practicable. He who attempts it must surely ... run the greater risks than he who tries to guess better than the crowd how the crowd will behave.”

Keynes proceeded to discuss his celebrated beauty contest example, whereby members of the public voted not for whom they thought was the prettiest, but whom other voters would find most appealing. It is important to bear in mind that herding is most likely to occur in situations where the decisions of others are observable, as it is not possible to copy what cannot be observed. Moreover, herding is likely to occur where decisions are taken sequentially so as to allow agents to observe the decisions of other agents.

The Asian economic and financial crises spurred the growth in research of the tendency of financial market participants to display mob-like instincts. As foreign investors fled to safety, the mass exodus of capital may be likened to animal herds where, as soon as a few investors flee, the rest follow. de Brouwer (2001) has argued that large macro hedge funds were the leaders responsible for encouraging the herd to liquidate investments, as many market participants believed that macro hedge funds possessed superior information and expertise. 
The prospect that a few large market participants could destabilise global capital markets has led many to argue for reforms to the international financial system in order to limit the impacts of such systemic risks. Consequently, testing for the presence of herding in financial markets is a highly topical issue in the international finance literature, especially as there have been few empirical papers related to the existence of herding.

Many explanations for the existence of herding have been proposed, such as imperfect information and the nature of compensation in managerial contracts. Becker's (1991) restaurant example shows that, when confronted with different choices and without private information, agents may base their decisions upon the number of patrons. This outcome may arise because previous patrons are believed to have made their decisions based upon private signals regarding quality. While many theoretical models have been proposed, a test of herding behaviour by economic agents is problematic. Part of this problem stems from an inability to observe directly the cognitive processes underlying the actions of agents. Various measures of herding have been devised to overcome these problems, but most empirical research has presented only indirect tests of the theoretical models proposed in the literature.

This paper provides a direct test of herding behaviour among small futures traders, specifically whether the futures positions of large speculators affect small trader portfolios. While large speculators are often blamed for significant market fluctuations, with the empirical literature focusing almost exclusively on institutional herding, analysing small traders is important for a number of reasons. First, small traders often comprise a large segment of markets, and can destabilise markets by moving in herds. Second, de Brouwer (2001, pp. 64-66) shows that large players often seek to manipulate small traders, so that the reactions of small traders to large speculators is an important consideration in analysing the effects of large traders on market prices. Third, small traders may, as the models outlined below predict, exacerbate price movements in their trading patterns. The seemingly excessive volatility of financial markets relative to fundamentals has long been a topic of fascination among financial economists. Examining the behaviour of small traders also contributes to an understanding of market dynamics.

The plan of the paper is as follows. Section 2 reviews the theoretical and empirical results in the literature. Section 3 outlines a direct test for the existence of herding among small futures traders. The data to be used for testing the theory are analysed in Section 4, and the volatility 
models and empirical results are reported in Section 5. Section 6 presents some concluding comments.

\section{Literature Review}

\subsection{Theory}

Herding is defined as a conscious decision by agents to mimic the actions of others. Thus, herding is a deliberate decision, which should not be confused with correlated decision making that is purely incidental. In the case of financial markets, investors have access to common information sets and may employ similar techniques in evaluating this information. Therefore, agents may behave in a similar manner, not through consciously following the actions of others, but through acting upon the same information. For example, noise traders, such as in the models of Kyle (1985) and De Long et al. (1990a), may employ similar technical trading strategies which result in significant correlations. However, this type of behaviour does not represent herding because the actions of other noise traders play no part in individual investment decisions. Consequently, the detection of herding can be difficult because, if group decisions are correlated, their decisions need to be decomposed into those components arising from information and from herding.

In the presence of uncertainty, mimicking the decision of others may be perfectly rational, so that herding need not be associated with irrational behaviour. However, the herding equilibrium may not be socially efficient and prices may be more volatile than if agents had acted independently of each other. Invaluable surveys of the rational herding literature are given in Devenow and Welch (1996), Bikhchandani and Sharma (2000) and Brunnermeier (2001). Herding may arise for a variety of reasons. Managerial remuneration often depends upon reputation, but the principals may be uncertain of managerial quality. Thus, poor managers have an incentive to copy the decisions of other managers in order to mask their inferiority. The model of Scharfstein and Stein (1990) is of this type, but lies outside the scope of the paper. Agents may also be compensated according to performance relative to their peers. In this instance, risk-averse managers will be unlikely to deviate from their peers, and will tend to cluster in their portfolio decisions. As shown in the models of Roll (1992) and 
Admati and Pfleiderer (1997), such contracts result in inefficient outcomes. Models of reputational herding lie outside the focus of this paper.

The type of herding most directly related to the context of futures market traders is based on the theory of information cascades, as in Banerjee (1992), Bikhchandani et al. (1992), Welch (1992), and Avery and Zemsky (1998). An information cascade arises when decisions are made by each agent sequentially, but agents begin to ignore their private signals in favour of the observed actions of previous agents. ${ }^{1}$ These signals are generally either 'good' or 'bad' and, importantly, agents cannot observe the signals received by other agents. ${ }^{2}$ However, the probability of the good or bad signal can be inferred from the actions of others, which are assumed to be observable. As agents are unsure of the quality of the signals, the actions of others are used to update their beliefs about, for example, the true value of an asset. Using Bayes' rule, given a sequence of decisions, if the suggested course of action implied by an agent's private signal is in conflict with the decisions of others, the sheer weight of numbers may cause agents to discard their private information and use the decisions of others to herd.

In the models cited above, the probability of a cascade beginning with the first few agents is high. Bikhchandani et al. (1992) show that herding is more likely, the less certain is an individual of the private signal. Moreover, if the signals received are noisy, and hence provide little certainty, the probability that the herd arrives at an incorrect decision (such as failing to invest when they should) will be high. This illustrates that herding can lead to inefficient social outcomes, despite the fact that agents have acted in a self-interested and rational manner. Thus, in situations where agents are prone to herd, the market mechanism cannot be used to reach a socially efficient outcome.

Furthermore, the theoretical models illustrate that cascades are fragile. Cascades imply that prices reflect only a narrow information set, so the arrival of new information can lead agents to re-evaluate their choices and cause the cascade to shatter. This suggests that herds can quickly reverse their decisions, which has implications for the time series properties of futures market traders. If traders are in an information cascade, it follows that, with a constant supply of news to the market, relatively little persistence should be observed in their positions. New information will result in the cascade shattering and noise traders altering their positions. If

\footnotetext{
${ }^{1}$ Bikhchandani et al. (1998) provide a review of the theory underlying information cascades.

2 The relevance of cascades has been questioned by, for example, Shiller (1995, p. 183).
} 
the positions of traders are persistent, this would provide indirect evidence against the existence of information cascades. However, these models cannot be tested directly because neither the order of decisions nor the decision making process of agents can be observed.

The fragility of information cascades has important consequences for financial market stability. If the herd is prone to alter its positions, then herding will cause financial markets to be excessively volatile. Thus, if small trader positions are random, this may provide evidence that would support policies aimed at limiting the extent of noise trading. Furthermore, herding reduces the information content of prices. Those who trade after a cascade has started provide no information to subsequent traders because they are merely copying the actions of others. As prices do not impound all private information, prices can be socially inefficient. ${ }^{3}$ This also explains why cascades are fragile, as they are based on relatively little information. With the arrival of new information, agents may find these signals to be more informative and alter their decisions, so that the cascade shatters.

A crucial assumption in the development of information cascade herding (ICH) models is whether prices are fixed or respond to supply and demand. Avery and Zemsky (1998) develop a model that allows prices to be flexible, in which case the situation faced by subsequent agents is not the same. If financial markets are competitive, then prices adjust to reflect all publicly available information, so that investors with only public information will be indifferent between buying or selling. If a trader is privately informed and trades, this information is revealed and impounded into prices. Consequently, an information cascade is prevented from forming, thereby making financial market prices informationally efficient. However, the model of Avery and Zemsky (1998) shows that if there are two types of traders, namely well informed and poorly informed, and the proportion of these traders in the market is not common knowledge, then herding can arise. If prices are flexible, uncertainty regarding investment values is insufficient to create herding incentives. Prices will not be efficient, even though agents have acted rationally.

\subsection{Empirical Literature}

\footnotetext{
${ }^{3}$ Froot et al. (1992) present another type of herding model. Based on pay-off externalities, they show why prices may not necessarily embody all relevant information. Traders are allowed to have short-term investment horizons so that, if a particular piece of information is unlikely to be reflected in prices in the short run, there will be no incentive for agents to acquire such information. Agents herd on only some information, which may not
} 
While the theoretical literature is well developed, the empirical literature has performed only indirect tests of the various herding theories, which stems from an inability to observe the reasons why agents make their decisions. Consequently, tests have been developed that are consistent with the existence of herding. However, as described below, the tests are typically necessary, but no sufficient, for herding. Therefore, it is not known to what extent agents accommodate the decisions of others in their decision making. A major limitation in any test of herding is the inability to separate intentional herding from coincidental decision making, in which agents may appear to make similar decisions through possessing similar information, while paying no attention to the actions of others. Such an observation would result in correlated decisions, but would not imply the existence of herding.

Lakonishok et al. (1992) developed a measure of herding among mutual fund managers. Their procedure tests whether the actual number of investors buying or selling a particular stock differs from the expected number of investors buying or selling if agents were to make their decisions independently. Although they concluded that money managers do not exhibit herding, Bikhchandani and Sharma (2000) noted that they had only analysed the correlation in trading patterns which, while consistent with herding, does not guarantee its existence. Using the test of Lakonishok et al. (1992), Wermers (1999) found some evidence of herding in seasonally unadjusted quarterly data of mutual fund managers.

According to Bikhchandani and Sharma (2000, p.18), a serious limitation of the method of Lakonishok et al. (1992) is that the method only considers the number of traders and pays little attention to the amount or value of the assets traded. As these studies also use quarterly data, this would make the detection of herding less likely as information received during this time interval is likely to swamp any information obtained from observing the positions of other funds managers. Moreover, the ability to observe the portfolios of other managers may be restricted due to reporting requirements, so that funds managers would find it difficult to determine the portfolio decisions of others in a timely manner. Tentative evidence for herding has also been found by Grinblatt et al. (1995), Nofsinger and Sias (1999), Choe et al. (1999) and Chang et al. (2000). While some have found little indication of herding, those who have concluded that herding exists have typically only tested the correlation among traders. As 
discussed above, such evidence is insufficient to conclude that herding exists among financial market participants.

Another approach to test for the presence of herding is that adopted by Christie and Huang (1995), and extended by Chang et al. (2000), who examine the presence of herding across a variety of international equity markets. Christie and Huang (1995) define the cross-sectional standard deviation, defined as:

$\operatorname{CSSD}_{t}=\sqrt{\frac{\sum_{i=1}^{N}\left(R_{i, t}-R_{m, t}\right)^{2}}{N-1}}$

where $\mathrm{R}_{m, \mathrm{t}}$ is the average of the $N$ returns in the market portfolio at time $t$ and $\mathrm{R}_{\mathrm{i}, t}$ is the stock return of firm $i$ at time $t$. This captures how stock returns are spread around the average return. Christie and Huang (1995) assert that traditional asset pricing theory predicts that the dispersion of returns increases with market returns due to different stock sensitivities to market returns. In periods of herding, stock returns will tend to cluster around the market returns. Chang et al. (2000) show that, under rational asset pricing models, the dispersion of stock returns is an increasing linear function of market returns.

The CSSD measure given above is used in the following equation:

$\operatorname{CSSD}_{t}=\alpha+\beta^{L} D_{t}^{L}+\beta^{U} D_{t}^{U}+\varepsilon_{t}$

in which $D_{t}^{L}$ ( $D_{t}^{U}$ ) takes the value 1 if the market return at time $t$ is in the extreme lower (upper) tail of the distribution, and zero otherwise, with 'extreme' defined as being in the top or bottom one (or five) percent of the distribution of returns. The logic underlying such a specification is that traders are more likely to herd in times of heightened uncertainty and market turbulence, so that extreme market moves should result in stock returns being less dispersed around the market average. Chang et al. (2000) also estimate the model for periods when the market return is positive and when it is negative. While no evidence of herding was found to exist for the USA or Hong Kong, partial evidence was found for Japan, and evidence in favour of herding was found for South Korea and Taiwan. 
Other researchers have provided tests of reputational herding models by testing the extent to which investment newsletters and security analysts herd among each other. Graham (1999) reports that newsletters with high reputations are more likely to herd in their recommendations in order to protect reputation. Welch (2000) explores the importance of consensus among security analysts in determining their recommendations. The idea behind such tests is that analysts who differ from average are likely to be judged harshly if they are wrong. However, if all analysts are wrong, no analyst would be criticised as agents would infer that it was difficult to anticipate. Welch (2000) finds evidence that consensus influences the revisions of analysts, as do the two most recent revisions. Such evidence suggests there is a tendency for investment analysts to herd.

Kodres and Pritsker (1996) examine herding among large futures traders, where size is determined by the Commodity Futures Trading Commission (CFTC). Daily data were analysed for large positions on interest rate futures, S\&P 500 composite index, British pound, Canadian dollar, Deutsche mark, Japanese yen and Swiss franc for the period August 1992 to August 1994. Large traders were disaggregated into numerous categories such as commercial banks, hedge funds and mutual funds. Correlation coefficients were calculated among the various trader types, and were found to be statistically significant in only 5 of 29 cases. A probit model was used to test the extent to which the probability of buying by one agent depended on the decisions of others. However, the analysis is still subject to the qualification that such alleged herding may be coincidental rather than genuine.

Moreover, Kodres and Pritsker (1996) examined only whether sub-categories of large traders herd. As small traders were neglected, they overlooked a potentially important group of traders with incentives to herd. Small traders do not have the resources or expertise of large traders. As small traders may be acting on inferior information, they may not possess the skills to decipher information releases appropriately. Therefore, small traders have an incentive to view large traders for guidance as to the appropriate course of action. The assumption made by small traders is that large traders, acting upon superior information, disclose the signals received through their trading activities. Consequently, an examination of the tendency of small traders to herd, based on the activities of large traders, is an important and neglected area that is worth of serious empirical consideration.

\section{A Direct Test for Herding}


Although the theoretical models presented above do not yield direct tests, they do provide guidance in constructing an appropriate empirical specification. Data for individual trades are not available according to the traders involved. The models of Kyle (1985), De Long et al. (1990a) and Shalen (1993) distinguish among traders based on the information at their disposal. Small traders are typically assumed to be naïve as they use past prices in making investment decisions, and are also presumed to form extrapolative expectations of future prices. This suggests a lag structure to accommodate the possibility that small traders use recent price changes to determine their futures positions. Including contemporaneous price changes also accommodates fundamentals, as prices will respond to news concerning fundamentals in an efficient market. Small traders may also exhibit some reaction to fundamental news, so that contemporaneous prices are likely to be an important factor in explaining the futures positions of small traders.

As described below, futures market position data are used to measure small traders and large speculators. Therefore, the empirical results are conditioned on total open interest in futures markets as futures activity may vary over time. Small traders may exhibit persistence in their positions as investments are typically undertaken with a general time horizon in mind. For this reason, the positions of small traders are likely to depend on their positions in previous periods. If previous small trader positions are important, and are correlated with other variables, the omission of previous small trader positions would bias the estimates and their standard errors.

A primary motivation for this paper is to test for herding among futures market participants, namely small traders, which is measured by including the lagged positions of large futures speculators. Such large speculators are assumed to be informed traders because their size allows them to acquire high quality information. Moreover, there is an incentive for large speculators to invest considerable time and resources in evaluating the information at their disposal. As the actions of large speculators may provide an externality to small traders by revealing the implicit information and expectations of large traders, this provides a direct test of herding by small traders. The empirical model is dynamic and is estimated with a lag length of one, as weekly data are used and higher-order lags quickly become dated because news arrives continuously. With a constant supply of news, it is unlikely that herding would be observed using information based on two lags. 
The empirical specification is given by

$$
\text { netsmall }_{t}=\beta_{0}+\beta_{1} \text { netsmall }_{t-1}+\beta_{2} \text { netl arg } e_{t-1}+\beta_{3} O I_{t}+\beta_{4} \text { spotret }_{t}+\beta_{5} \text { spotret }_{t-1}+u_{t}
$$

where netsmall is defined as the difference between long and short non-reportable positions, as compiled by the CFTC, netlarge represents large non-commercial trader series (or speculators), OI is the total open interest in the futures series, spotret is the log-difference of spot prices observed between time $t$ and $t-1$, and $\mathrm{u}_{\mathrm{t}}$ is assumed to be an independent and identically distributed random shock with zero mean and unit variance. Equation (1) will be estimated by ordinary least squares (OLS). The null hypothesis of herding is $\mathrm{H}_{0}: \beta_{2}=0$. If small traders herd according to large speculators, than net large speculators should have a positive impact on the positions of small traders, so that herding implies the alternative hypothesis, $\mathrm{H}_{\mathrm{A}}: \beta_{2}>0$. In order to test whether small traders form extrapolative expectations and investment decisions, as in De Long et al. (1990a), the null hypothesis is $\mathrm{H}_{0}: \beta_{5}=0$. If small traders simply trade on the basis of trends in market prices, then $\mathrm{H}_{\mathrm{A}}: \beta_{5}>0$, which means their positions are changed in the same direction as past price changes.

\section{Data and Empirical Analysis}

Specification (1) indicates that data are required on the positions of small traders, large speculators, open interest and spot market returns. The Commitments of Trader (CoT) reports compiled by the CFTC, which is the regulatory body of the US futures and options markets, are used to measure the prevalence of small traders, large hedgers and large speculators. Traders of sufficient size, as defined in the CFTC regulations, are required to declare their purpose in trading futures. If futures trading is conducted to mitigate or control risks for a commercial enterprise that relies on the underlying asset, such traders are classified as commercial traders, or 'large hedgers'. Large traders who do not have an underlying business that relies upon the asset for commercial purposes are termed 'non-commercial' traders, or 'large speculators'. 
Traders deemed by the CFTC not to be of sufficient size to be classified as large are collectively reported as non-reportable positions, which we will call 'small traders'. These small traders may use futures to hedge or speculate, but are not required to declare their interest in using futures because of their size. The literature has typically assumed such traders to be poorly informed relative to large traders, which appears reasonable as information and trading are costly in both time and resources. Therefore, small traders are less likely than large traders to have access to high quality information, and also less likely to be able to disseminate information released to the market. Small traders are, therefore, more likely than large traders to employ simple trading rules based on readily observable historical price movements. In this paper, it is assumed that small traders act as noise traders of the type described in Kyle (1985), Black (1986) and De Long et al. (1990a). As data on noise traders have become available only recently, the direct tests of herding behaviour proposed in this paper were not viable when these papers were published.

Small traders possess less information and have an incentive to consider the positions of better informed large traders, and hence are prone to herding behaviour. Large traders not only use better information but will also have expended greater efforts in interpreting such information. As trading positions reveal their decisions, small traders would be expected to benefit by examining the positions of large traders in formulating their own portfolios. Consequently, the use of data on small futures traders is a direct test of the existence of herding. Data on the position of large traders and non-reportable (or small trader) positions were compiled from the CFTC's web-site (www.cftc.gov), which reports weekly positions. It will be recalled from Section 2 that many herding studies have used quarterly data, which is arguably not sufficiently frequent to be useful for tests of herding. Thus, weekly data are more likely to provide direct evidence of herding. Furthermore, it is important to recognise that participation in futures markets varies over time, so that including the total amount of futures market open interest is likely to be important. The open interest data were obtained from Datastream.

The impact of historical price movements was outlined above. In order to measure this impact, spot market data for all assets were downloaded from Datastream. The use of spot market data serves several useful purposes. As outlined in Bessembinder and Seguin (1992), the existence of futures markets has been argued to exert a destabilising influence on the underlying spot markets. This paper provides an interesting perspective on the effect of 
futures market participants on the underlying asset market. Furthermore, futures contracts expire periodically so that the construction of a continuous series requires certain assumptions as to the rolling over of futures contracts. The use of spot market data circumvents this issue. Finally, the use of spot rates instead of futures prices is not expected to affect significantly the results for the markets examined. As these are typically viewed as cash-and-carry markets, future supply conditions do not influence the spread between spot and futures markets (see Neftci (1996, p. 4)).

Tables 1 to 9 report the summary statistics of the data series used in this paper. The sample is for the period 6 October 1992, when the CFTC began releasing weekly data, to 15 October 2002, giving 521 weekly observations. On average, mean returns for each currency market imply that each currency depreciated against the USD, which displayed significant strength over this period. The S\&P 500 index provided positive capital gains, on average, reflecting the high returns of US equities. In contrast, the Nikkei 225 lost value as the Japanese economy faltered, with deflation and the bursting of the asset price bubble. Consistent with previous studies, mean weekly returns appear to have a non-Gaussian distribution, with the Lagrange Multiplier test of normality $(\mathrm{LM}(\mathrm{N}))$ rejecting the null hypothesis at the one percent level for all returns. Indeed, normality is rejected for most of the data. From the sample skewness and kurtosis statistics reported in Tables 1 to 9, it seems that returns have fatter tails than the normal distribution, which has been widely documented in financial time series. Conversely, the number of contracts data is most often thin-tailed, with kurtosis coefficients less than three. Moreover, it appears that the data are not highly skewed, so that normality is most likely rejected due to kurtosis that differs from the normal distribution.

A noteworthy observation is that the mean number of futures contracts of large hedgers was negative, making them net sellers, for AUD, CAD, oil, gold, S\&P 500 and Nikkei 225 futures contracts. This indicates that these commodities were produced by large hedgers who sought certainty in the price at which they could sell their products. For example, oil companies and gold miners could use futures to lock in the future price of their commodities, and fund managers could use S\&P 500 and Nikkei 225 futures to lock in the value of their portfolios and to manage exposure to market risk. Table 9 shows that the mean values of large speculator and small trader contracts were positive. It follows that speculators lost money on the Japanese stock market as it depreciated, on average, yet speculators maintained long positions over this period. 
It is an interesting issue to examine what types of hedgers employ currency futures through the use of survey questionnaires. Australia runs a current account deficit, and so imports more than it exports, and large hedgers tend to be net sellers of AUD. If only exporters and importers used futures contracts for hedging, this would suggest that importers are more active participants in futures markets than are exporters. Conversely, the USA is a large importer from Japan, and large hedgers tend to be net buyers of Japanese yen. This is consistent with the direction of trade between the USA and Japan, as importers would be expected to outweigh exporters in hedging yen because of the nature of the current account deficit. Therefore, the relationship between a country's trade position and the nature of those hedging its currency would be worth investigating to determine the reasons for which agents hedge currency risk, and on which side of the market they operate. 
TABLE 1 -Summary Statistics for AUD

SMALL represents net small trader positions, SPEC is net large speculator positions, OI is futures market open interest, SPOTRET denotes spot market logarithmic returns, HEDGE represents net large hedger positions, $\mathrm{LM}(\mathrm{N})$ is the Lagrange Multiplier test of normality, and ADF is the augmented Dickey-Fuller test of a unit root.

\begin{tabular}{l|lllll}
\hline Statistic & SPOTRET & SMALL & HEDGE & SPEC & OI \\
\hline Mean & 0.0005 & 957 & -953 & 51.8 & 17768 \\
Median & 0.0000 & 179.00 & 0.0000 & 0.0000 & 17586 \\
Std Dev & 0.0130 & 4610 & 8992 & 4972 & 9957 \\
Skewness & -0.026 & 1.305 & -1.131 & 1.030 & 0.691 \\
Kurtosis & 3.668 & 5.364 & 5.507 & 6.109 & 3.459 \\
LM(N) & $9.742^{* *}$ & $269.10^{* *}$ & $247.54^{* *}$ & $301.96^{* *}$ & $46.084^{* *}$ \\
ADF & $-15.870^{* *}$ & $-4.157^{* *}$ & $-5.043^{* *}$ & $-5.4896^{* *}$ & $-3.835^{* *}$ \\
\hline
\end{tabular}

** $(*)$ denotes significance at the one (five) percent level.

\section{TABLE 2 -Summary Statistics for CAD}

SMALL represents net small trader positions, SPEC is net large speculator positions, OI is futures market open interest, SPOTRET denotes spot market logarithmic returns, HEDGE represents net large hedger positions, $\mathrm{LM}(\mathrm{N})$ is the Lagrange Multiplier test of normality, and ADF is the augmented Dickey-Fuller test of a unit root.

\begin{tabular}{l|lllll}
\hline Statistic & SPOTRET & SMALL & HEDGE & SPEC & OI \\
\hline Mean & 0.0005 & 6956 & -4350 & -2606 & 55155 \\
Median & 0.0008 & 6457 & -3641 & -2461 & 55343 \\
Std Dev & 0.0073 & 7596 & 19041 & 13523 & 16805 \\
Skewness & 0.0490 & 0.162 & -0.392 & 0.258 & -0.089 \\
Kurtosis & 4.063 & 2.610 & 3.168 & 3.346 & 2.147 \\
LM(N) & $24.725^{* *}$ & 5.570 & $13.967^{* *}$ & $8.379^{*}$ & $16.481^{* *}$ \\
ADF & $-15.974^{* *}$ & $-4.737^{* *}$ & $-5.702^{* *}$ & $-5.552^{* *}$ & $-4.404^{* *}$ \\
\hline
\end{tabular}

** $(*)$ denotes significance at the one (five) percent level. 
TABLE 3 -Summary Statistics for GBP

SMALL represents net small trader positions, SPEC is net large speculator positions, OI is futures market open interest, SPOTRET denotes spot market logarithmic returns, HEDGE represents net large hedger positions, $\mathrm{LM}(\mathrm{N})$ is the Lagrange Multiplier test of normality, and ADF is the augmented Dickey-Fuller test of a unit root.

\begin{tabular}{l|lllll}
\hline Statistic & SPOTRET & SMALL & HEDGE & SPEC & OI \\
\hline Mean & -0.0002 & 392 & 1041 & -649 & 42612 \\
Median & 0.0002 & 1156 & 3029 & -1863 & 40719 \\
Std Dev & 0.0116 & 7501 & 18800 & 12169 & 12283 \\
Skewness & -0.386 & -0.191 & -0.186 & 0.240 & 0.467 \\
Kurtosis & 5.139 & 1.933 & 2.470 & 3.479 & 2.742 \\
LM(N) & $112.314^{* *}$ & $27.869^{* *}$ & $9.114^{*}$ & $10.001^{* *}$ & $20.347^{* *}$ \\
ADF & $-17.166^{* *}$ & $-6.4597^{* *}$ & $-7.532^{* *}$ & $-7.983^{* *}$ & $-7.073^{* *}$ \\
\hline
\end{tabular}

** $(*)$ denotes significance at the one (five) percent level.

\section{TABLE 4 -Summary Statistics for JPY}

SMALL represents net small trader positions, SPEC is net large speculator positions, OI is futures market open interest, SPOTRET denotes spot market logarithmic returns, HEDGE represents net large hedger positions, $\mathrm{LM}(\mathrm{N})$ is the Lagrange Multiplier test of normality, and ADF is the augmented Dickey-Fuller test of a unit root.

\begin{tabular}{l|lllll}
\hline Statistic & SPOTRET & SMALL & HEDGE & SPEC & OI \\
\hline Mean & $4.61 \mathrm{E}-05$ & -8183 & 20289 & -12106 & 84698 \\
Median & 0.0017 & -10157 & 26485 & -13179 & 80631 \\
Std Dev & 0.0161 & 10733 & 29895 & 20805 & 22777 \\
Skewness & -0.659 & 0.509 & -0.449 & 0.293 & 0.879 \\
Kurtosis & 5.948 & 2.516 & 2.468 & 2.791 & 3.872 \\
LM(N) & $237.17^{* *}$ & $25.66^{* *}$ & $21.822^{* *}$ & $7.111330^{*}$ & $72.031^{* *}$ \\
ADF & $-15.518^{* *}$ & $-5.753^{* *}$ & $-5.769^{* *}$ & $-5.695^{* *}$ & $-6.361^{* *}$ \\
\hline
\end{tabular}

** $(*)$ denotes significance at the one (five) percent level. 
TABLE 5 -Summary Statistics for SFR

SMALL represents net small trader positions, SPEC is net large speculator positions, OI is futures market open interest, SPOTRET denotes spot market logarithmic returns, HEDGE represents net large hedger positions, $\mathrm{LM}(\mathrm{N})$ is the Lagrange Multiplier test of normality, and ADF is the augmented Dickey-Fuller test of a unit root.

\begin{tabular}{l|lllll}
\hline Statistic & SPOTRET & SMALL & HEDGE & SPEC & OI \\
\hline Mean & 0.0003 & 2788 & 7921 & -5133 & 49255 \\
Median & 0.0006 & 3677 & 12304 & -6857 & 47632 \\
Std Dev & 0.0155 & 9211 & 23169 & 15034 & 12909 \\
Skewness & -0.206 & -0.465 & -0.245 & 0.060 & 0.849 \\
Kurtosis & 4.415 & 2.446 & 2.207 & 2.713 & 4.256 \\
LM(N) & $47.110^{* *}$ & $25.431^{* *}$ & $18.854^{* *}$ & 2.0946 & $96.861^{* *}$ \\
ADF & $-16.895^{* *}$ & $-5.992^{* *}$ & $-6.410^{* *}$ & $-6.237^{* *}$ & $-6.708^{* *}$ \\
& & & & & \\
\hline
\end{tabular}

** $(*)$ denotes significance at the one (five) percent level.

\section{TABLE 6 -Summary Statistics for Oil}

SMALL represents net small trader positions, SPEC is net large speculator positions, OI is futures market open interest, SPOTRET denotes spot market logarithmic returns, HEDGE represents net large hedger positions, $\mathrm{LM}(\mathrm{N})$ is the Lagrange Multiplier test of normality, and ADF is the augmented Dickey-Fuller test of a unit root.

\begin{tabular}{l|lllll}
\hline Statistic & SPOTRET & SMALL & HEDGE & SPEC & OI \\
\hline Mean & 0.0007 & 764 & -7088 & 400468 & 434186 \\
Median & 0.0027 & 559 & -7560 & 399888 & 425073 \\
Std Dev & 0.0506 & 12557 & 39124 & 56915 & 67067 \\
Skewness & -0.218 & 0.001 & -0.080 & 0.261 & 0.735 \\
Kurtosis & 4.491 & 3.098 & 2.660 & 2.942 & 3.562 \\
LM(N) & $52.354^{* *}$ & 0.2105 & 3.0596 & 5.9795 & $53.777^{* *}$ \\
ADF & $-18.920^{* *}$ & $-5.170^{* *}$ & $-4.8072^{* *}$ & $-3.519 * *$ & $-3.712^{*} !$ \\
& & & & & \\
\hline
\end{tabular}

** $(*)$ denotes significance at the one (five) percent level. 
TABLE 7 -Summary Statistics for Gold

SMALL represents net small trader positions, SPEC is net large speculator positions, OI is futures market open interest, SPOTRET denotes spot market logarithmic returns, HEDGE represents net large hedger positions, $\mathrm{LM}(\mathrm{N})$ is the Lagrange Multiplier test of normality, and ADF is the augmented Dickey-Fuller test of a unit root.

\begin{tabular}{l|lllll}
\hline Statistic & SPOTRET & SMALL & HEDGE & SPEC & OI \\
\hline Mean & -0.0002 & 11063 & -493 & -105670 & 161254 \\
Median & -0.0008 & 8448 & 4640 & -13550 & 163643 \\
Std Dev & 0.0169 & 11985 & 45742 & 35326 & 30947 \\
Skewness & 1.649 & 0.673 & -0.208 & 0.044 & -0.332 \\
Kurtosis & 16.781 & 2.599 & 2.122 & 2.229 & 2.695 \\
LM(N) & $4359.07^{* *}$ & $42.771^{* *}$ & $20.488^{* *}$ & $13.068^{* *}$ & $11.567^{* *}$ \\
ADF & $-17.376^{* *}$ & $-4.0950^{* *}$ & $-4.412^{* *}$ & $-4.560^{* *}$ & $-5.0520^{* *}$ \\
\hline
\end{tabular}

** $(*)$ denotes significance at the one (five) percent level.

\section{TABLE 8 -Summary Statistics for S\&P 500}

SMALL represents net small trader positions, SPEC is net large speculator positions, OI is futures market open interest, SPOTRET denotes spot market logarithmic returns, HEDGE represents net large hedger positions, $\mathrm{LM}(\mathrm{N})$ is the Lagrange Multiplier test of normality, and ADF is the augmented Dickey-Fuller test of a unit root.

\begin{tabular}{l|lllll}
\hline Statistic & SPOTRET & SMALL & HEDGE & SPEC & OI \\
\hline Mean & 0.0014 & 17839.8 & -4076 & -13763.8 & 426018.7 \\
Median & 0.0035 & 6239 & 6486 & -13772 & 404720 \\
Std Dev & 0.0234 & 31538.8 & 37345 & 12435 & 64316 \\
Skewness & -0.309 & 1.217 & -0.938 & 0.144 & 1.238 \\
Kurtosis & 6.407 & 3.450 & 2.959 & 3.366 & 4.399 \\
LM(N) & $260.299^{* *}$ & $132.914^{* *}$ & $76.462^{* *}$ & 4.722 & $175.649^{* *}$ \\
ADF & $-17.428^{* *}$ & $-3.422^{*} !$ & $-3.019 !$ & $-3.787^{* *}$ & $-4.051^{* * !}$ \\
& & & & & \\
\hline
\end{tabular}

** $(*)$ denotes significance at the one (five) percent level. ! represents ADF with trend. 
TABLE 9 -Summary Statistics for Nikkei 225

SMALL represents net small trader positions, SPEC is net large speculator positions, OI is futures market open interest, SPOTRET denotes spot market logarithmic returns, HEDGE represents net large hedger positions, $\mathrm{LM}(\mathrm{N})$ is the Lagrange Multiplier test of normality, and ADF is the augmented Dickey-Fuller test of a unit root.

\begin{tabular}{l|lllll}
\hline Statistic & SPOTRET & SMALL & HEDGE & SPEC & OI \\
\hline Mean & -0.0013 & 1077.6 & -2073.8 & 996.2 & 21361.9 \\
Median & -0.0029 & 1247 & -2513 & 1118 & 20050 \\
Std Dev & 0.0338 & 1254.7 & 3177.3 & 2732.5 & 6312.1 \\
Skewness & 0.480 & -0.147 & 0.085 & 0.206 & 1.009 \\
Kurtosis & 3.844 & 2.670 & 2.355 & 2.513 & 4.010 \\
LM(N) & $35.470^{* *}$ & 4.226 & $9.676^{* *}$ & $8.833^{*}$ & $110.60^{* *}$ \\
ADF & $-16.320^{* *}$ & $-5.198^{* *}$ & $-3.925^{*} !$ & $-4.151^{* * !}$ & $-4.093^{* *}$ \\
\hline
\end{tabular}

** $(*)$ denotes significance at the one (five) percent level. ! represents ADF with trend. 
The time series properties of each data set are analysed to enable the use of appropriate econometric techniques. ADF tests are used to establish whether a series displays nonstationary behaviour, with the lag length selected according to the Schwarz information criterion. Deterministic trends were included for those series where it was deemed appropriate. For most series, the ADF test rejected the null hypothesis of a unit root which, given the low power of the test, is a strong result. The only series for which the null hypothesis was not rejected was large hedgers of S\&P 500 futures contracts. Hence, the use of OLS appears to be justified, and transformation of the data is generally unnecessary. In order to accommodate possible non-stationarity, the data were also transformed to first differences to obtain stationarity, but with essentially the same quantitative outcomes. These results are available from the authors upon request.

Although small traders may be unable to influence markets individually, they may comprise a sufficiently large segment of the market so as to make their collective behaviour influential. Figures 1 to 9 present the time series of the proportions of total open interest by each trader type. These figures illustrate that non-reportable, or small trader, positions can comprise a substantial proportion of future positions, and that their importance varies across both time and markets. Small traders comprise between 20 to 40 percent of most markets, with small traders being the least prevalent in the oil market (Figure 5), holding roughly ten percent of contracts. The proportion of small traders in the market is the highest of the three trader types for GBP and SFR, and is relatively constant over time at around fifty percent. In general, these figures demonstrate that, as small traders comprise a significant proportion of futures positions, they could destabilise market prices if they were to move as a herd.

In all other markets, large hedgers are the dominant trader type. With three trader types and total market open interest being observable, only two trader types need to be analysed as the third can be inferred. The correlation coefficients reported in Table 10 between small traders and large speculators, and between small traders and large hedgers, suggest that the trading behaviour of small traders most closely resembles that of large speculators. Interestingly, the correlation coefficients are larger in absolute value with hedgers than with speculators, but are negative. This suggests a very important function performed by noise traders in financial 
markets, namely as providers of liquidity, as outlined in Black (1986), which enables hedgers to manage risk.

Except for GBP and SFR, large speculators and non-reportable, or small, positions are positively correlated. It is possible that small traders in GBP and SFR are primarily hedgers, which would explain the positive correlation. The positive correlations for the other markets suggest that small traders and large speculators share similar information. However, correlation is a necessary, but not sufficient condition, for the existence of herding. If herding were to exist, the results in Table 10 suggest that it is most likely to be between small traders and large speculators. 
Figure 1 - AUD

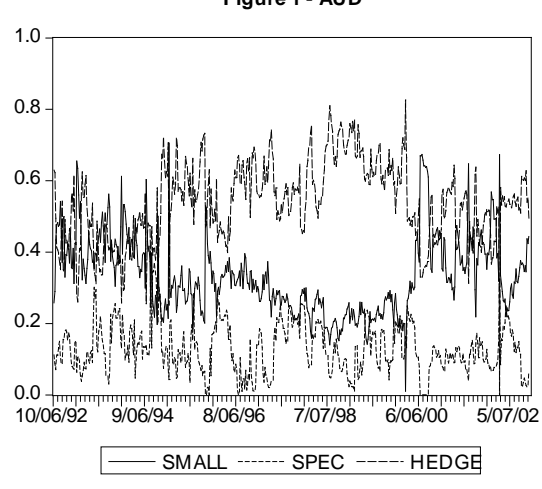

Figure 3 - GBP

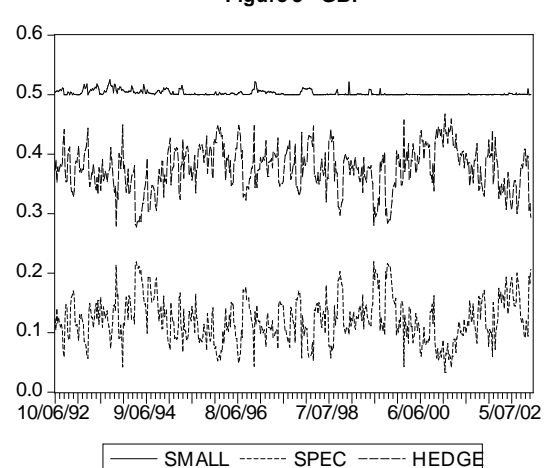

Figure 5 - SFR

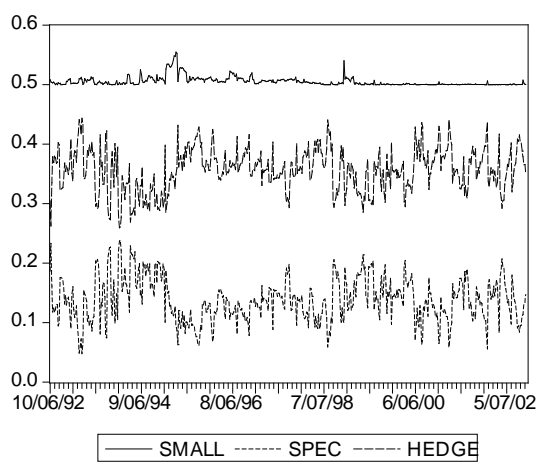

Figure 7 - Gold

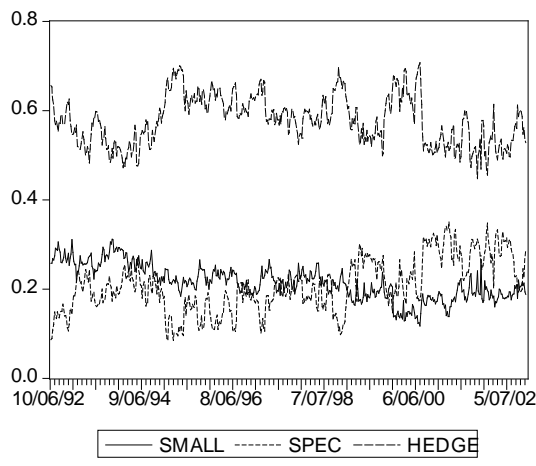

Figure 2 - CAD

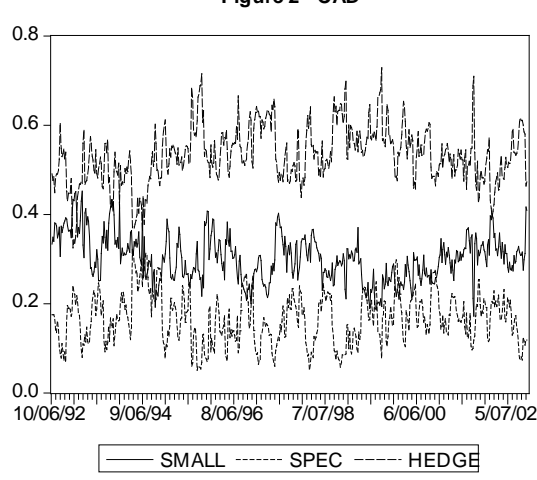

Figure 4 - JPY

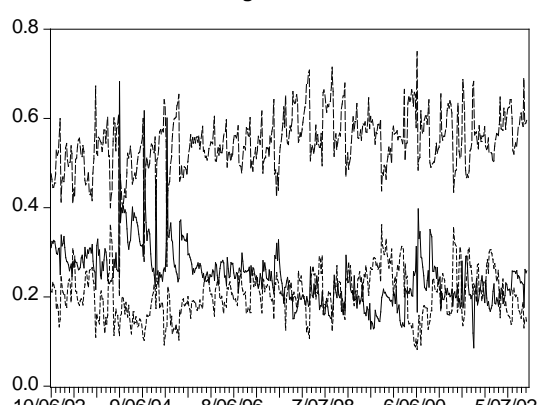

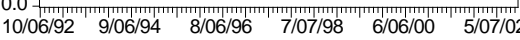

- SMALL ------ SPEC ----- HEDG

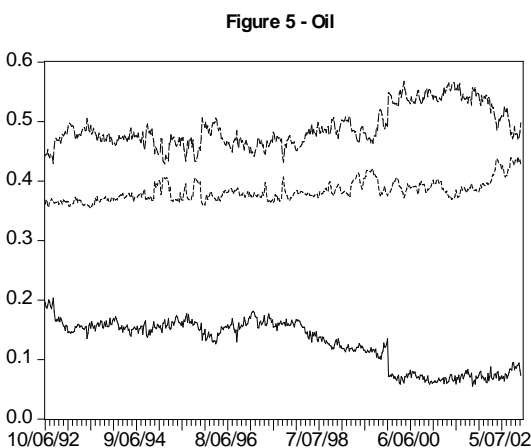

— SMALL ------ SPEC ----- HEDGE

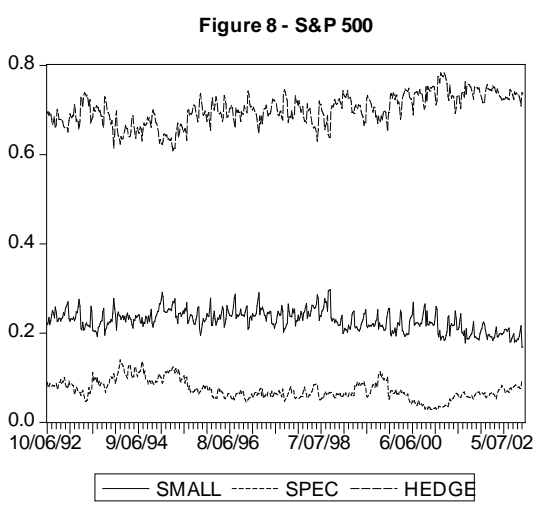




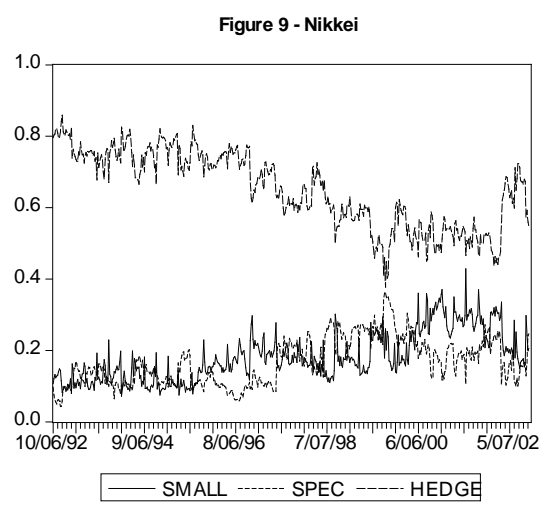

TABLE 10 - CORRELATIONS BETWEEN SMALL AND LARGE TRADERS

\begin{tabular}{l|lllllllll}
\hline Large Trader & $A U D$ & CAD & GBP & JPY & SFR & Oil & Gold & SP500 & Nikkei \\
\hline & & & & & & & & & \\
Speculator & 0.797 & 0.594 & -0.816 & 0.774 & -0.816 & 0.240 & 0.827 & 0.313 & 0.155 \\
Hedger & -0.910 & -0.821 & 0.928 & -0.898 & 0.927 & -0.860 & -0.901 & -0.949 & -0.528 \\
& & & & & & & & & \\
\hline
\end{tabular}




\section{Volatility Models and Estimation}

\subsection{Herding Models}

Table 11 provides tests of the hypothesis that small traders do not herd according to the positions of large traders, specifically in terms of the number of contracts of net small speculators. The estimates are obtained by OLS, with consistent Newey-West (1987) standard errors (using a truncation lag of five) in the presence of possible autocorrelation and heteroskedasticity. Given the insignificant t-ratios for one-period lagged net large speculators in 7 of 9 cases, the null hypothesis of no herding among small traders in future markets is generally not rejected. The theoretical models argue that agents may be prone to herding in the presence of better informed agents. In this context, it appears that small traders do not consider the previous positions of large speculators in trading futures contracts. The only markets for which the null hypothesis of no herding is rejected are S\&P 500 and Nikkei 225 at the one and five percent levels, respectively. Net small traders exhibit significant persistence, as indicated by lagged small traders, in the region of 0.81-0.96. Moreover, except for S\&P 500 and Nikkei 225, lagged net large speculators provide no incremental explanatory power of contracts held by net small traders over small traders in the previous period.

All the coefficients for lagged small traders are positive and exceed 0.809, suggesting that small traders are positively autocorrelated. Thus, small traders do not trade erratically or randomly as their positions reflect a high degree of persistence. Another interesting implication of the results is how prices influence the positions of small traders. The results suggest that small traders employ extrapolative strategies, so that if the past value of the asset has increased (decreased), small traders will purchase (sell) the asset. In interpreting the impact of exchange rate returns on small traders, the method used to quote exchange rates is that, exchange rates except for GBP, are quoted as foreign currency per unit of USD.

Therefore, positive returns indicate that the foreign currency has depreciated, and negative returns indicate that the foreign currency has appreciated. Thus, the negative estimated coefficients indicate that, as a foreign currency appreciates (depreciates), small traders tend to buy (sell) foreign currency. Small traders also seem to destabilise oil prices, as indicated by the positive coefficient on lagged spot oil returns. As oil appreciates, small traders increase 
the amount of oil purchases, thereby adding impetus to price changes in the previous period and causing prices to overshoot the equilibrium level in the absence of such noise trading.

This pattern of trading behaviour is consistent with expectations as to how small noise traders formulate their trading strategies. Being small, they do not have the resources to acquire costly information, and hence tend to rely on price movements to determine their investments. The coefficients of lagged spot returns were statistically significant in the currency and oil markets, suggesting that small traders may cause currency markets to be unstable. As small traders would add impetus to price movements in currency markets, prices would overshoot the equilibrium in a market without noise traders. Therefore, small traders seem to act in a manner that is consistent with theoretical models, such as in De Long et al. (1990a).

While the ADF tests in Section 4 rejected the null hypothesis of a unit root for most series, small traders displayed a high degree of persistence, as indicated by the lagged coefficients in the region 0.81-0.96. Given the high persistence of small traders, the model was also estimated in first differences of net small traders, net large speculators and open interest in order to accommodate unit roots. The estimates are reported in Table 12, with the implications for herding differing between the two sets of estimates. Estimated using first differences, the data do not reject the null hypothesis of no herding for S\&P and Nikkei, unlike the results in Table 11, but reject no herding for CAD, GBP and gold futures at the one percent level. The positive and significant coefficients are consistent with small traders mimicking the previous positions of large speculators, indicating that small traders herd on the positions of large speculators for CAD, GBP and gold.

The model estimated in first differences confirms the previous estimates that small traders change their positions in the same direction as price changes in the underlying asset. Lagged changes in small traders are insignificant for AUD, JPY, SFR, gold and S\&P, which is consistent with a high-degree of persistence in the small trader series for these commodities. For commodities with significant lagged changes in small trader positions, namely CAD, GBP, oil and Nikkei, the negative and significant coefficient estimates imply that, if the commodity has appreciated in the previous period, small traders will purchase the asset, on average. 


\section{TABLE 11. HERDING IN NUMBER OF CONTRACTS OF NET SMALL TRADERS: OLS}

OLS estimates of the number of contracts held by net small traders (NET SMALL). NET LARGE represents the number of net large speculation contracts, OI is total futures market open interest, and SPOTRET denotes spot market returns. The sample is 521 observations, from 6 October 1992 to 10 October 2002. LM(SC) is the LM test of serial correlation with up to 12 lags, LM(ARCH) is the LM test of ARCH effects with up to 12 lags, and the t-ratios are based on the Newey-West standard errors with a truncation lag of five.

\begin{tabular}{|c|c|c|c|c|c|c|c|c|c|}
\hline Market & $C$ & $\begin{array}{c}N E T \\
\text { SMALL } \\
(-1)\end{array}$ & $\begin{array}{c}N E T \\
L A R G E \\
(-1)\end{array}$ & $\overline{O I}$ & $\begin{array}{l}\text { SPOT } \\
R E T\end{array}$ & $\begin{array}{c}\text { SPOT } \\
R E T(-1)\end{array}$ & $\bar{R}^{2}$ & $\begin{array}{c}L M \\
(S C)\end{array}$ & $\begin{array}{c}L M \\
(A R C H)\end{array}$ \\
\hline AUD & $\begin{array}{r}-151.49 \\
-1.66\end{array}$ & $\begin{array}{r}0.9351 \\
42.11^{* *}\end{array}$ & $\begin{array}{r}-0.0175 \\
-0.71\end{array}$ & $\begin{array}{l}0.016 \\
2.42 *\end{array}$ & $\begin{array}{r}-63482.7 \\
-9.39 * *\end{array}$ & $\begin{array}{r}-37224.2 \\
-8.05^{* *}\end{array}$ & 0.926 & 15.98 & $35.90 * *$ \\
\hline CAD & $\begin{array}{r}-161.11 \\
-0.59\end{array}$ & $\begin{array}{r}0.9034 \\
54.46^{* *}\end{array}$ & $\begin{array}{r}-0.0025 \\
-0.31\end{array}$ & $\begin{array}{l}0.0179 \\
2.96 * *\end{array}$ & $\begin{array}{r}-237654 \\
-11.94 * *\end{array}$ & $\begin{array}{c}-96466.5 \\
-5.77 * *\end{array}$ & 0.909 & $38.83 * *$ & 10.31 \\
\hline GBP & $\begin{array}{r}178.036 \\
0.40\end{array}$ & $\begin{array}{r}0.8123 \\
24.21^{* *}\end{array}$ & $\begin{array}{r}0.0215 \\
1.18\end{array}$ & $\begin{array}{r}-0.0036 \\
-0.37\end{array}$ & $\begin{array}{r}232038 \\
10.06^{* *}\end{array}$ & $\begin{array}{l}58941 \\
4.92 * *\end{array}$ & 0.855 & $419.5^{* *}$ & 15.36 \\
\hline JPY & $\begin{array}{r}-777.23 \\
-1.39\end{array}$ & $\begin{array}{r}0.8638 \\
37.40^{* *}\end{array}$ & $\begin{array}{r}-0.0056 \\
-0.51\end{array}$ & $\begin{array}{r}-0.0049 \\
-0.80\end{array}$ & $\begin{array}{r}-170274 \\
-8.13^{* *}\end{array}$ & $\begin{array}{r}-57867.3 \\
-5.26 * *\end{array}$ & 0.888 & 6.03 & 15.32 \\
\hline SFR & $\begin{array}{r}-202.85 \\
-0.44\end{array}$ & $\begin{array}{r}0.8883 \\
37.47^{* *}\end{array}$ & $\begin{array}{r}-0.0155 \\
-1.12\end{array}$ & $\begin{array}{r}-0.0021 \\
-0.22\end{array}$ & $\begin{array}{l}-181924 \\
-10.92 * *\end{array}$ & $\begin{array}{l}-56406 \\
-7.30 * *\end{array}$ & 0.907 & $427.8 * *$ & $24.43^{*}$ \\
\hline Oil & $\begin{array}{r}-1574.76 \\
-1.06\end{array}$ & $\begin{array}{r}0.8090 \\
35.543^{* *}\end{array}$ & $\begin{array}{r}-0.0042 \\
-0.36\end{array}$ & $\begin{array}{r}0.0077 \\
0.74\end{array}$ & $\begin{array}{r}51719.4 \\
8.47 * *\end{array}$ & $\begin{array}{r}28110.8 \\
6.03^{* *}\end{array}$ & 0.765 & $21.17 *$ & $27.89 * *$ \\
\hline Gold & $\begin{array}{r}540.01 \\
0.73\end{array}$ & $\begin{array}{r}0.8897 \\
26.392 * *\end{array}$ & $\begin{array}{r}0.0168 \\
1.72\end{array}$ & $\begin{array}{r}0.0056 \\
1.09\end{array}$ & $\begin{array}{r}156435 \\
4.98 * *\end{array}$ & $\begin{array}{r}-415.83 \\
-0.03\end{array}$ & 0.903 & 17.52 & $64.53^{* *}$ \\
\hline S\&P & $\begin{array}{r}-2472.35 \\
1.08\end{array}$ & $\begin{array}{r}0.9629 \\
71.798 * *\end{array}$ & $\begin{array}{l}0.0880 \\
3.70 * *\end{array}$ & $\begin{array}{r}0.0104 \\
1.71\end{array}$ & $\begin{array}{r}19775.4 \\
1.16\end{array}$ & $\begin{array}{r}3091.1 \\
0.26\end{array}$ & 0.971 & 18.85 & $35.56^{* *}$ \\
\hline Nikkei & $\begin{array}{r}161.90 \\
1.63\end{array}$ & $\begin{array}{r}0.8460 \\
27.40^{* *}\end{array}$ & $\begin{array}{r}0.0229 \\
2.23^{*}\end{array}$ & $\begin{array}{r}-0.0008 \\
-0.18\end{array}$ & $\begin{array}{r}721.06 \\
0.81\end{array}$ & $\begin{array}{r}-443.931 \\
-0.42\end{array}$ & 0.731 & $23.53 *$ & $75.34^{* *}$ \\
\hline
\end{tabular}

** (*) denotes significance at the one (five) percent level. 
Significant results for both contemporaneous and lagged spot returns are reported for AUD, CAD, JPY, SFR and oil. Contemporaneous returns are significant for GBP, and lagged returns are significant for gold. Given the methods used to quote exchange rates, the signs of the coefficients are consistent with extrapolative trading strategies that would destabilise prices. The significance of contemporaneous returns may reflect reactions to fundamentals that result in price changes. However, the significance of lagged returns is consistent with markets being more volatile than in the absence of noise traders, who use strategies that fuel price changes and create short term price momentum.

Diagnostic tests may suggest possible deficiencies in model specification and the robustness of the empirical results. The use of Newey-West standard errors provides consistent and valid inferences in the presence of serial correlation and heteroskedasticity. In most cases, the null hypotheses of no serial correlation and no ARCH effects are rejected by the Lagrange Multiplier tests, $\mathrm{LM}(\mathrm{SC})$ and $\mathrm{LM}(\mathrm{ARCH})$, respectively. The interaction between these tests in unclear, but it is well known that ARCH effects can lead tests of serial correlation to overreject the null hypothesis of no serial correlation. Furthermore, if ARCH effects are present, the error terms are likely to be leptokurtic, and hence non-normal.

\subsection{Volatility Models}

In order to improve efficiency and the robustness of the empirical results, ARCH effects were modelled and incorporated in estimation. The $\operatorname{GARCH}(1,1)$, exponential GARCH(1,1) (or EGARCH(1,1), developed by Nelson (1990)), and GJR(1,1) (see Glosten et al. (1993)) processes are used to model the conditional variance of small traders. Engle (1982) proposed the univariate $\operatorname{ARCH}(p)$ process:

$\varepsilon_{t}=\eta_{t} \sqrt{h_{t}}$

where $\varepsilon_{t}$ is the unconditional shock, $\eta_{t}$ is an independently and identically distributed standardized (or conditional) shock with zero mean and unit variance, $\mathrm{h}_{\mathrm{t}}$ is the conditional variance of $\varepsilon_{t}$, given by 
$h_{t}=\omega+\sum_{i=1}^{p} \alpha_{i} \varepsilon_{t-i}^{2}$

and $\omega>0, \alpha_{i} \geq 0(i=1, \ldots, p)$ are sufficient conditions to ensure that the conditional variance is non-negative for all t. The $\alpha_{i}$ (or ARCH) parameter contributes to the short run persistence of shocks, $\sum_{i=1}^{p} \alpha_{i}$. It is standard practice to assume that $\eta_{\mathrm{t}}$ is normally distributed, in which case maximizing the likelihood function yields the maximum likelihood estimator (MLE). If $\eta_{\mathrm{t}}$ is not normal, the estimation method leads to the quasi-MLE (QMLE).

Bollerslev (1986) extended $\mathrm{ARCH}(p)$ to the generalized ARCH model, GARCH( $p, q)$, by specifying the conditional variance as

$h_{t}=\omega+\sum_{i=1}^{p} \alpha_{i} \varepsilon_{t-i}^{2}+\sum_{j=1}^{q} \beta_{j} h_{t-j}$

in which $\omega>0, \alpha_{i} \geq 0(\mathrm{i}=1, \ldots, p)$ and $\beta_{j} \geq 0(\mathrm{j}=1, \ldots q)$ are sufficient for $h_{t}>0$ for all t. As for $\operatorname{ARCH}(p)$, the $\alpha_{i}$ (or $\left.\mathrm{ARCH}\right)$ parameter contributes to the short run persistence of shocks, $\sum_{i=1}^{p} \alpha_{i}$, while the $\beta_{j}$ (or GARCH) parameter is the contribution to long run persistence, $\sum_{i=1}^{p} \alpha_{i}+\sum_{j=1}^{q} \beta_{j}$. The GARCH process gives a parsimonious representation of the dynamic structure of the conditional variance and has been applied to a wide array of financial data, as surveyed in, for example, Bollerslev et al. (1992), Bollerslev et al. (1994), Li et al. (2002), McAleer (2005), and Caporin and McAleer (2012).

In practice, the GARCH(1,1) model has provided an adequate representation of many financial series, as indicated by the standardized shocks displaying no significant ARCH effects. However, stock returns series have been shown to exhibit significant asymmetric effects, in that the sign of the lagged unconditional shock can affect the conditional variance significantly. A popular parsimonious representation of asymmetric conditional volatility is the EGARCH(1,1) model of Nelson (1990), namely

$$
\ln h_{t}=\omega+\alpha\left|\eta_{t-1}\right|+\gamma \eta_{t-1}+\beta \ln h_{t-1}, \quad|\beta|<1 .
$$


As EGARCH is specified in terms of the logarithm of the conditional variance, $h_{t}$ is guaranteed to be positive without imposing any parameter restrictions. Nelson (1990) proved that $|\beta|<1$ ensures stationarity and ergodicity for EGARCH(1,1). Shephard (1996) postulates that $|\beta|<1$ is likely to be sufficient for consistency of the QMLE for $\operatorname{EGARCH}(1,1)$. McAleer et al. (2007) argue that $|\beta|<1$ is also a sufficient condition for the existence of moments. The only obvious limitation of the EGARCH model is the absence of asymptotic properties for the QMLE.

The GJR(1,1) model of Glosten et al. (1993) also captures possible asymmetries in the response of conditional volatility to past unconditional shocks, and is given as

$h_{t}=\omega+\left[\alpha+\gamma I\left(\varepsilon_{t-1}\right)\right] \varepsilon_{t-1}^{2}+\beta h_{t-1}$

where $\omega>0, \alpha+\gamma \geq 0$ and $\beta \geq 0$ are sufficient conditions for $h_{t}>0$, and $I\left(\varepsilon_{t}\right)$ is an indicator variable defined by:

$I\left(\varepsilon_{t}\right)= \begin{cases}1, & \varepsilon_{t}<0 \\ 0, & \varepsilon_{\mathrm{t}} \geq 0\end{cases}$

which allows the sign of past shocks to have a different impact on volatility, as measured by $\gamma$. Furthermore, $\gamma$ affects both the short run and long run persistence of shocks, $\alpha+\frac{\gamma}{2}$ and $\alpha+\beta+\frac{\gamma}{2}$, respectively. The GJR model may be preferable to EGARCH in that the structural and statistical properties have been established. 
TABLE 12. HERDING IN FIRST DIFFERENCE OF NUMBER OF CONTRACTS OF NET SMALL TRADERS: IID

OLS estimates of the first difference of the number of contracts held by net small traders (dNET SMALL). dNETLARGE represents the first difference in the number of net large speculation contracts, dOI is the first difference of total futures market open interest, and SPOTRET denotes spot market returns. The sample is 520 observations from 6 October 1992 to 10 October 2002. LM(SC) is the LM test of serial correlation with up to 12 lags, $\mathrm{LM}(\mathrm{ARCH})$ is the LM test of ARCH effects with up to 12 lags, and the tratios are based on the Newey-West standard errors with a truncation lag of five.

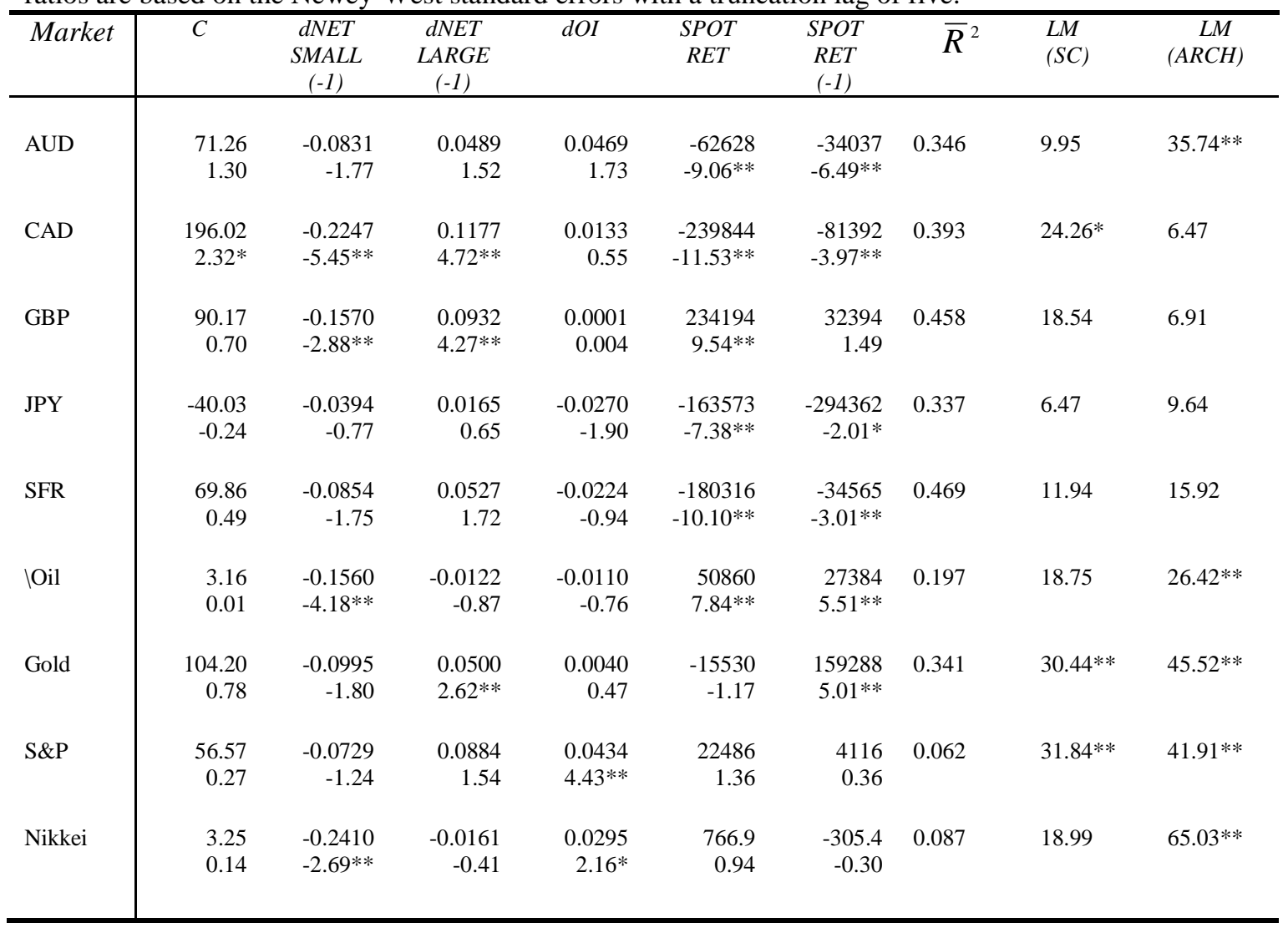

** $(*)$ denotes significance at the one (five) percent level. 
TABLE 13. HERDING IN NUMBER OF CONTRACTS OF NET SMALL TRADERS: GARCH(1,1)

QMLE for the GARCH $(1,1)$ model of the number of contracts held by net small speculators (NETSML). NET LRGE represents the number of net large speculation contracts, OI is total futures market open interest, and SPOTRET denotes spot market returns. The sample is 521 observations from 6 October 1992 to 10 October 2002.

\begin{tabular}{|c|c|c|c|c|c|c|c|c|c|}
\hline Market & $C$ & $\begin{array}{c}N E T \\
\text { SML } \\
(-1) \\
\end{array}$ & $\begin{array}{c}\text { NET } \\
L R G E \\
(-1) \\
\end{array}$ & $O I$ & $\begin{array}{c}\text { SPOT } \\
R E T\end{array}$ & $\begin{array}{c}\text { SPOT } \\
R E T \\
(-1) \\
\end{array}$ & $\omega$ & $\alpha$ & $\beta$ \\
\hline AUD & $\begin{array}{r}-43.79 \\
-0.61\end{array}$ & $\begin{array}{r}0.8887 \\
32.61^{* *}\end{array}$ & $\begin{array}{r}0.0156 \\
0.70\end{array}$ & $\begin{array}{r}0.0127 \\
2.41 *\end{array}$ & $\begin{array}{r}-48394 \\
-16.21^{* *}\end{array}$ & $\begin{array}{l}-28528 \\
-8.31^{* *}\end{array}$ & $\begin{array}{r}5899 \\
2.51^{*}\end{array}$ & $\begin{array}{l}0.0326 \\
4.58^{* *}\end{array}$ & $\begin{array}{r}0.9685 \\
144.54^{* *}\end{array}$ \\
\hline CAD & $\begin{array}{r}-68.58 \\
-0.18\end{array}$ & $\begin{array}{r}0.9064 \\
46.99 * *\end{array}$ & $\begin{array}{r}-0.0035 \\
-0.32\end{array}$ & $\begin{array}{r}0.0165 \\
2.05 *\end{array}$ & $\begin{array}{r}-244373 \\
-19.45^{* *}\end{array}$ & $\begin{array}{c}-97977 \\
-7.77 * *\end{array}$ & $\begin{array}{r}7254184 \\
4.96^{* *}\end{array}$ & $\begin{array}{r}0.0941 \\
1.88\end{array}$ & $\begin{array}{r}-0.5364 \\
-2.03^{*}\end{array}$ \\
\hline GBP & $\begin{array}{r}-173.40 \\
-0.40\end{array}$ & $\begin{array}{r}0.8262 \\
29.69 * *\end{array}$ & $\begin{array}{r}-0.0174 \\
-1.02\end{array}$ & $\begin{array}{r}0.0050 \\
0.53\end{array}$ & $\begin{array}{c}-258414 \\
-30.93^{* *}\end{array}$ & $\begin{array}{c}-72877 \\
-5.40 * *\end{array}$ & $\begin{array}{r}1684637 \\
2.98 * *\end{array}$ & $\begin{array}{l}0.1201 \\
2.90^{* *}\end{array}$ & $\begin{array}{l}0.6567 \\
6.92 * *\end{array}$ \\
\hline JPY & $\begin{array}{r}-817.83 \\
-1.45\end{array}$ & $\begin{array}{r}0.8722 \\
38.67 * *\end{array}$ & $\begin{array}{r}-0.0094 \\
-0.88\end{array}$ & $\begin{array}{r}-0.0044 \\
-0.65\end{array}$ & $\begin{array}{l}-171740 \\
-24.85^{* *}\end{array}$ & $\begin{array}{l}-59833 \\
-5.29 * *\end{array}$ & $\begin{array}{r}3861820 \\
0.88\end{array}$ & $\begin{array}{r}0.0370 \\
1.14\end{array}$ & $\begin{array}{r}0.6539 \\
1.76\end{array}$ \\
\hline SFR & $\begin{array}{r}338.97 \\
0.73\end{array}$ & $\begin{array}{r}0.9002 \\
37.26^{* *}\end{array}$ & $\begin{array}{r}0.0207 \\
1.62\end{array}$ & $\begin{array}{r}-0.0013 \\
-0.15\end{array}$ & $\begin{array}{r}176816 \\
25.81^{* *}\end{array}$ & $\begin{array}{r}56853 \\
6.01 * *\end{array}$ & $\begin{array}{r}1043020 \\
2.68 * *\end{array}$ & $\begin{array}{l}0.0870 \\
2.99 * *\end{array}$ & $\begin{array}{r}0.7848 \\
12.11^{* *}\end{array}$ \\
\hline Oil & $\begin{array}{r}-3453.06 \\
-1.78\end{array}$ & $\begin{array}{r}0.8251 \\
35.65^{* *}\end{array}$ & $\begin{array}{r}-0.0053 \\
-0.44\end{array}$ & $\begin{array}{r}0.0131 \\
1.26\end{array}$ & $\begin{array}{r}51581 \\
11.47^{* *}\end{array}$ & $\begin{array}{r}29063 \\
5.74 * *\end{array}$ & $\begin{array}{r}18900020 \\
4.56^{* *}\end{array}$ & $\begin{array}{r}0.0086 \\
0.29\end{array}$ & $\begin{array}{l}0.3438 \\
2.54 * *\end{array}$ \\
\hline Gold & $\begin{array}{r}583.03 \\
0.79\end{array}$ & $\begin{array}{r}0.9020 \\
40.56^{* *}\end{array}$ & $\begin{array}{r}0.0116 \\
1.44\end{array}$ & $\begin{array}{r}0.0041 \\
0.82\end{array}$ & $\begin{array}{r}175504 \\
38.45^{* *}\end{array}$ & $\begin{array}{r}20708 \\
1.65\end{array}$ & $\begin{array}{r}6101450 \\
3.24 * *\end{array}$ & $\begin{array}{l}0.1306 \\
3.79 * *\end{array}$ & $\begin{array}{r}0.3289 \\
1.84\end{array}$ \\
\hline S\&P & $\begin{array}{r}219.16 \\
0.12\end{array}$ & $\begin{array}{r}0.9758 \\
86.75^{* *}\end{array}$ & $\begin{array}{l}0.0549 \\
3.00 * *\end{array}$ & $\begin{array}{r}0.0020 \\
0.44\end{array}$ & $\begin{array}{r}16113 \\
2.15\end{array}$ & $\begin{array}{r}5280 \\
0.50\end{array}$ & $\begin{array}{r}18278519 \\
6.28 * *\end{array}$ & $\begin{array}{l}0.3519 \\
5.11^{* *}\end{array}$ & $\begin{array}{r}0.0697 \\
0.71\end{array}$ \\
\hline Nikkei & $\begin{array}{r}-151.56 \\
-1.78\end{array}$ & $\begin{array}{r}0.9192 \\
45.57 * *\end{array}$ & $\begin{array}{r}0.0166 \\
1.82\end{array}$ & $\begin{array}{l}0.0119 \\
3.95^{* *}\end{array}$ & $\begin{array}{r}2049 \\
3.85^{* *}\end{array}$ & $\begin{array}{r}329.51 \\
0.43\end{array}$ & $\begin{array}{r}197648 \\
10.52 * *\end{array}$ & $\begin{array}{l}0.4810 \\
5.18^{* *}\end{array}$ & $\begin{array}{r}0.1482 \\
2.90^{*}\end{array}$ \\
\hline
\end{tabular}

** (*) denotes significance at the one (five) percent level. 
TABLE 14. HERDING IN NUMBER OF CONTRACTS OF NET SMALL TRADERS: GJR(1,1)

QMLE for the GJR(1,1) model of the number of contracts held by net small speculators (NETSML). NET LRGE represents the number of net large speculation contracts, OI is total futures market open interest, and SPOTRET denotes spot market returns. The sample is 521 observations from 6 October 1992 to 10 October 2002.

\begin{tabular}{|c|c|c|c|c|c|c|c|c|c|c|}
\hline Market & $C$ & $\begin{array}{c}N E T \\
S M L \\
(-1) \\
\end{array}$ & $\begin{array}{c}\text { NET } \\
L R G E \\
(-1) \\
\end{array}$ & $O I$ & $\begin{array}{c}\text { SPOT } \\
R E T\end{array}$ & $\begin{array}{c}\text { SPOT } \\
R E T \\
(-1) \\
\end{array}$ & $\omega$ & $\alpha$ & $\beta$ & $\gamma$ \\
\hline AUD & $\begin{array}{l}22.38 \\
0.14\end{array}$ & $\begin{array}{l}0.9284 \\
40.73^{* *}\end{array}$ & $\begin{array}{l}-0.0093 \\
-0.53\end{array}$ & $\begin{array}{l}0.0078 \\
1.11\end{array}$ & $\begin{array}{l}-56421 \\
-13.17^{* *}\end{array}$ & $\begin{array}{l}-33768 \\
-6.89 * *\end{array}$ & $\begin{array}{l}899274 \\
6.85\end{array}$ & $\begin{array}{l}0.4038 \\
2.53^{*}\end{array}$ & $\begin{array}{l}0.3265 \\
3.69 * *\end{array}$ & $\begin{array}{l}-0.4216 \\
-2.66 * *\end{array}$ \\
\hline CAD & $\begin{array}{l}32.11 \\
0.08\end{array}$ & $\begin{array}{l}0.9097 \\
43.89 * *\end{array}$ & $\begin{array}{l}-0.0044 \\
-0.39\end{array}$ & $\begin{array}{l}0.0150 \\
1.86\end{array}$ & $\begin{array}{l}-244160 \\
-20.25^{* *}\end{array}$ & $\begin{array}{l}-96456 \\
-7.49 * *\end{array}$ & $\begin{array}{l}2969775 \\
1.35\end{array}$ & $\begin{array}{l}0.0750 \\
1.39\end{array}$ & $\begin{array}{l}0.3963 \\
0.90\end{array}$ & $\begin{array}{l}-0.1167 \\
-1.89\end{array}$ \\
\hline GBP & $\begin{array}{l}-132.71 \\
-0.31\end{array}$ & $\begin{array}{l}0.8131 \\
30.91 * *\end{array}$ & $\begin{array}{l}-0.0246 \\
-1.49\end{array}$ & $\begin{array}{l}0.0027 \\
0.29\end{array}$ & $\begin{array}{l}-264530 \\
-31.17^{* *}\end{array}$ & $\begin{array}{l}-78981 \\
-6.02 * *\end{array}$ & $\begin{array}{l}1262296 \\
3.45^{* *}\end{array}$ & $\begin{array}{l}0.0339 \\
1.27\end{array}$ & $\begin{array}{l}0.7288 \\
11.49^{* *}\end{array}$ & $\begin{array}{l}0.1340 \\
2.34 *\end{array}$ \\
\hline JPY & $\begin{array}{l}-800.10 \\
-1.43\end{array}$ & $\begin{array}{l}0.8717 \\
37.88 * *\end{array}$ & $\begin{array}{l}-0.0090 \\
-0.85\end{array}$ & $\begin{array}{l}-0.0047 \\
-0.70\end{array}$ & $\begin{array}{l}-172982 \\
-25.17^{* *}\end{array}$ & $\begin{array}{l}-60491 \\
-5.36 * *\end{array}$ & $\begin{array}{l}3117166 \\
0.90\end{array}$ & $\begin{array}{l}0.0148 \\
0.54\end{array}$ & $\begin{array}{l}0.7177 \\
2.38 *\end{array}$ & $\begin{array}{l}0.0371 \\
0.67\end{array}$ \\
\hline SFR & $\begin{array}{l}301.98 \\
0.67\end{array}$ & $\begin{array}{l}0.8976 \\
36.76^{* *}\end{array}$ & $\begin{array}{l}0.0188 \\
1.49\end{array}$ & $\begin{array}{l}-0.0011 \\
-0.13\end{array}$ & $\begin{array}{l}178886 \\
27.78 * *\end{array}$ & $\begin{array}{l}57257 \\
5.88 * *\end{array}$ & $\begin{array}{l}2126071 \\
2.48^{*}\end{array}$ & $\begin{array}{l}0.0922 \\
2.52 *\end{array}$ & $\begin{array}{l}0.6133 \\
4.71 * *\end{array}$ & $\begin{array}{l}0.0670 \\
1.08\end{array}$ \\
\hline Oil & $\begin{array}{l}-3417.3 \\
-1.76\end{array}$ & $\begin{array}{l}0.8227 \\
35.33^{* *}\end{array}$ & $\begin{array}{l}-0.0064 \\
-0.53\end{array}$ & $\begin{array}{l}0.0141 \\
1.35\end{array}$ & $\begin{array}{l}51606 \\
11.46^{* *}\end{array}$ & $\begin{array}{l}29019 \\
5.75^{* *}\end{array}$ & $\begin{array}{l}1890001 \\
8 \\
4.50 * *\end{array}$ & -0.0057 & $\begin{array}{l}0.3423 \\
2.52 * *\end{array}$ & $\begin{array}{l}0.0306 \\
0.57\end{array}$ \\
\hline Gold & $\begin{array}{l}378.23 \\
0.50\end{array}$ & $\begin{array}{l}0.9055 \\
41.18\end{array}$ & $\begin{array}{l}0.0107 \\
1.36\end{array}$ & $\begin{array}{l}0.0050 \\
1.00\end{array}$ & $\begin{array}{l}176360 \\
38.67\end{array}$ & $\begin{array}{l}20745 \\
1.71\end{array}$ & $\begin{array}{l}5732612 \\
2.69\end{array}$ & $\begin{array}{l}0.0551 \\
0.90\end{array}$ & $\begin{array}{l}0.3876 \\
1.92\end{array}$ & $\begin{array}{l}0.0912 \\
1.35\end{array}$ \\
\hline S\&P & $\begin{array}{l}543.34 \\
0.30\end{array}$ & $\begin{array}{l}0.9739 \\
85.26 * *\end{array}$ & $\begin{array}{l}0.0535 \\
2.92 * *\end{array}$ & $\begin{array}{l}0.0015 \\
0.32\end{array}$ & $\begin{array}{l}15039 \\
2.02 *\end{array}$ & $\begin{array}{l}5012 \\
0.49\end{array}$ & $\begin{array}{l}1827840 \\
0 \\
6.58 * *\end{array}$ & $\begin{array}{l}0.4986 \\
4.27^{* *}\end{array}$ & $\begin{array}{l}0.0653 \\
0.76\end{array}$ & $\begin{array}{l}-0.2490 \\
-1.85\end{array}$ \\
\hline Nikkei & $\begin{array}{l}-193.24 \\
-2.21 *\end{array}$ & $\begin{array}{l}0.9215 \\
44.32 * *\end{array}$ & $\begin{array}{l}0.0177 \\
1.97^{*}\end{array}$ & $\begin{array}{l}0.0128 \\
3.94^{* *}\end{array}$ & $\begin{array}{l}2089 \\
3.83^{* *}\end{array}$ & $\begin{array}{l}419.6 \\
0.55\end{array}$ & $\begin{array}{l}193171 \\
10.13^{* *}\end{array}$ & $\begin{array}{l}0.3027 \\
3.15^{* *}\end{array}$ & $\begin{array}{l}0.1438 \\
2.78 * *\end{array}$ & $\begin{array}{l}0.4220 \\
2.17^{*}\end{array}$ \\
\hline
\end{tabular}

** $(*)$ denotes significance at the one (five) percent level. 
TABLE 15. HERDING IN NUMBER OF CONTRACTS OF NET SMALL TRADERS: EGARCH(1,1)

QMLE for the EGARCH(1,1) model of the number of contracts held by net small speculators (NETSML). NET LRGE represents the number of net large speculation contracts, OI is total futures market open interest, SPOTRET denotes spot market returns. The sample is 521 observations from 6 October 1992 to 10 October 2002.

\begin{tabular}{|c|c|c|c|c|c|c|c|c|c|c|}
\hline Market & $C$ & $\begin{array}{c}N E T \\
S M L \\
(-1)\end{array}$ & $\begin{array}{c}\text { NET } \\
L R G E \\
(-1)\end{array}$ & $O I$ & $\begin{array}{l}\text { SPOT } \\
R E T\end{array}$ & $\begin{array}{c}\text { SPOT } \\
R E T \\
(-1)\end{array}$ & $\omega$ & $\alpha$ & $\gamma$ & $\beta$ \\
\hline AUD & $\begin{array}{l}87.32 \\
-1.26\end{array}$ & $\begin{array}{r}0.8982 \\
36.75^{* *}\end{array}$ & $\begin{array}{r}0.0169 \\
0.76\end{array}$ & $\begin{array}{l}0.0156 \\
3.01 * *\end{array}$ & $\begin{array}{r}-49918 \\
-16.71^{* *}\end{array}$ & $\begin{array}{c}-29327 \\
-8.66 * *\end{array}$ & $\begin{array}{r}0.024 \\
0.44\end{array}$ & $\begin{array}{l}0.1029 \\
3.88 * *\end{array}$ & $\begin{array}{r}-0.0233 \\
-1.22\end{array}$ & $\begin{array}{r}0.9932 \\
260.04^{* *}\end{array}$ \\
\hline CAD & $\begin{array}{r}119.7 \\
0.30\end{array}$ & $\begin{array}{r}0.9115 \\
43.79 * *\end{array}$ & $\begin{array}{r}-0.0061 \\
-0.55\end{array}$ & $\begin{array}{r}0.0131 \\
1.62\end{array}$ & $\begin{array}{l}-240582 \\
-19.63^{* *}\end{array}$ & $\begin{array}{l}-97978.3 \\
-7.635 * *\end{array}$ & $\begin{array}{r}8.873 \\
1.77\end{array}$ & $\begin{array}{r}0.0090 \\
0.13\end{array}$ & $\begin{array}{r}0.1227 \\
2.19 *\end{array}$ & $\begin{array}{r}0.4245 \\
1.31\end{array}$ \\
\hline GBP & $\begin{array}{r}-21.30 \\
-0.05\end{array}$ & $\begin{array}{r}0.8216 \\
28.81^{* *}\end{array}$ & $\begin{array}{r}-0.0214 \\
-1.19\end{array}$ & $\begin{array}{r}0.0004 \\
0.04\end{array}$ & $\begin{array}{l}-254507 \\
-29.71^{* *}\end{array}$ & $\begin{array}{r}-72385 \\
-5.431^{* *}\end{array}$ & $\begin{array}{r}2.094 \\
2.85^{* *}\end{array}$ & $\begin{array}{l}0.2007 \\
3.50 * *\end{array}$ & $\begin{array}{r}-0.0827 \\
-2.27 *\end{array}$ & $\begin{array}{r}0.8575 \\
18.09^{* *}\end{array}$ \\
\hline JPY & $\begin{array}{r}-849.5 \\
-1.53\end{array}$ & $\begin{array}{r}0.8825 \\
38.95 * *\end{array}$ & $\begin{array}{r}-0.0128 \\
-1.18\end{array}$ & $\begin{array}{r}-0.0035 \\
-0.52\end{array}$ & $\begin{array}{l}-176299 \\
-21.97 * *\end{array}$ & $\begin{array}{r}-58401 \\
-5.184 * *\end{array}$ & $\begin{array}{r}18.79 \\
2.91^{* *}\end{array}$ & $\begin{array}{r}0.1888 \\
2.21 *\end{array}$ & $\begin{array}{r}-0.0553 \\
-1.02\end{array}$ & $\begin{array}{r}-0.1592 \\
-0.40\end{array}$ \\
\hline SFR & $\begin{array}{r}403.1 \\
0.84\end{array}$ & $\begin{array}{r}0.9097 \\
38.79 * *\end{array}$ & $\begin{array}{r}0.0289 \\
2.35^{*}\end{array}$ & $\begin{array}{r}-0.0016 \\
-0.17\end{array}$ & $\begin{array}{r}180833 \\
25.11^{* *}\end{array}$ & $\begin{array}{r}56061 \\
6.194^{* *}\end{array}$ & $\begin{array}{r}0.796 \\
1.75\end{array}$ & $\begin{array}{l}0.1359 \\
2.58 * *\end{array}$ & $\begin{array}{r}0.0214 \\
1.05\end{array}$ & $\begin{array}{r}0.9434 \\
31.64^{* *}\end{array}$ \\
\hline Oil & $\begin{array}{r}-3147.1 \\
-1.72\end{array}$ & $\begin{array}{r}0.8190 \\
36.32 * *\end{array}$ & $\begin{array}{r}-0.0080 \\
-0.65\end{array}$ & $\begin{array}{r}0.0140 \\
1.44\end{array}$ & $\begin{array}{r}51649 \\
11.32 * *\end{array}$ & $\begin{array}{r}29087 \\
5.982^{* *}\end{array}$ & $\begin{array}{r}2.559 \\
1.38\end{array}$ & $\begin{array}{r}0.0541 \\
0.92\end{array}$ & $\begin{array}{r}-0.0329 \\
-1.01\end{array}$ & $\begin{array}{l}0.8484 \\
7.79 * *\end{array}$ \\
\hline Gold & $\begin{array}{r}221.6 \\
0.31\end{array}$ & $\begin{array}{r}0.9146 \\
44.38 * *\end{array}$ & $\begin{array}{r}0.0086 \\
1.18\end{array}$ & $\begin{array}{r}0.0051 \\
1.01\end{array}$ & $\begin{array}{r}162198 \\
37.37^{* *}\end{array}$ & $\begin{array}{r}1135 \\
0.1024\end{array}$ & $\begin{array}{l}3.451 \\
2.19 *\end{array}$ & $\begin{array}{l}0.2510 \\
4.51 * *\end{array}$ & $\begin{array}{r}-0.0257 \\
-0.61\end{array}$ & $\begin{array}{l}0.7760 \\
7.89 * *\end{array}$ \\
\hline S\&P & $\begin{array}{r}-2005.2 \\
-2.43^{*}\end{array}$ & $\begin{array}{r}0.9541 \\
85.35 * *\end{array}$ & $\begin{array}{l}0.0362 \\
3.63 * *\end{array}$ & $\begin{array}{l}0.0075 \\
3.80 * *\end{array}$ & $\begin{array}{r}19011 \\
2.35 *\end{array}$ & $\begin{array}{r}5436 \\
0.6014\end{array}$ & $\begin{array}{r}0.595 \\
17.74^{* *}\end{array}$ & $\begin{array}{l}-0.0741 \\
-3.79 * *\end{array}$ & $\begin{array}{l}0.1224 \\
5.87 * *\end{array}$ & $\begin{array}{r}0.9685 \\
532.57^{* *}\end{array}$ \\
\hline Nikkei & $\begin{array}{r}-142.3 \\
-1.82\end{array}$ & $\begin{array}{r}0.9234 \\
49.87 * *\end{array}$ & $\begin{array}{r}0.0156 \\
2.02 *\end{array}$ & $\begin{array}{l}0.0105 \\
3.61 * *\end{array}$ & $\begin{array}{r}2309 \\
4.48^{* *}\end{array}$ & $\begin{array}{l}1.538 \\
0.002\end{array}$ & $\begin{array}{r}6.043 \\
8.44^{* *}\end{array}$ & $\begin{array}{l}0.6985 \\
8.25^{* *}\end{array}$ & $\begin{array}{r}-0.1143 \\
-1.83\end{array}$ & $\begin{array}{l}0.4898 \\
8.55^{* *}\end{array}$ \\
\hline
\end{tabular}

** $\left(^{*}\right)$ denotes significance at the one (five) percent level. 
Tables 13-15 present the QMLE of the coefficients of the conditional mean and conditional variance of the $\operatorname{GARCH}(1,1), \operatorname{GJR}(1,1)$ and $\operatorname{EGARCH}(1,1)$ volatility models, respectively, in the absence of normality of the conditional shocks, $\eta_{t}$. The Bollerslev-Wooldridge (1992) robust standard errors are also presented in the absence of normality. EViews 3.0 was used to obtain the QMLE, and the Marquadt algorithm was employed to maximise the likelihood function, with the estimates converging in all cases. The QMLE are largely consistent with the OLS estimates. In the case of $\operatorname{GARCH}(1,1),, \operatorname{GJR}(1,1)$ and $\operatorname{EGARCH}(1,1)$, the null hypothesis of no herding is rejected for S\&P. There is a marginal rejection of no herding for Nikkei for $\operatorname{GARCH}(1,1)$, but the null hypothesis is rejected using GJR(1,1) and EGARCH(1,1), suggesting that small traders in Nikkei futures contracts exhibit asymmetric responses. EGARCH(1,1) also shows there is evidence against the null hypothesis of no herding for SFR.

The GARCH(1,1), GJR(1,1) and $\operatorname{EGARCH}(1,1)$ models were also estimated in first differences, for which the estimates are reported in Tables 16-18, respectively. These results are broadly similar to those presented in Table 12, as the null hypothesis of no herding is still rejected for the CAD, GBP and gold markets by all three models. Furthermore, the null hypothesis is also rejected for S\&P using $\operatorname{GARCH}(1,1)$ and $\operatorname{GJR}(1,1)$, and is marginally rejected by $\operatorname{EGARCH}(1,1)$. Generally, these models support the contention that net small traders (or speculators) display herding tendencies, as indicated by the statistically significant one-period lagged positions of net large speculators.

It will be recalled from Tables 11 and 12 that the ARCH(LM) test rejected the null hypothesis of no ARCH effects for small traders in AUD and non-currencies, but SFR displayed ARCH effects when estimated in levels. The significance of the conditional volatility estimates is generally consistent with these results. In virtually all of the models of AUD and noncurrency commodities, small traders have significant conditional volatility. Despite the null hypothesis not being rejected by LM(ARCH), the GBP small trader model displays conditionally heteroskedastic effects. 
TABLE 16. HERDING IN FIRST DIFFERENCE OF NUMBER OF CONTRACTS OF NET SMALL TRADERS: GARCH(1,1)

QMLE for the GARCH(1,1) model of the first difference of the number of contracts held by net small speculators (dNETSML). dNETLRGE represents the first difference of the number of net large speculation contracts, dOI is the first difference of total futures market open interest, and SPOTRET denotes spot market returns. The sample is 520 observations from 6 October 1992 to 10 October 2002.

\begin{tabular}{|c|c|c|c|c|c|c|c|c|c|}
\hline Market & $C$ & $\begin{array}{c}d N E T \\
S M L \\
(-1) \\
\end{array}$ & $\begin{array}{c}d N E T \\
L R G E \\
(-1) \\
\end{array}$ & $d O I$ & $\begin{array}{c}\text { SPOT } \\
R E T\end{array}$ & $\begin{array}{c}\text { SPOT } \\
R E T \\
(-1) \\
\end{array}$ & $\omega$ & $\alpha$ & $\beta$ \\
\hline AUD & $\begin{array}{r}78.21 \\
1.86\end{array}$ & $\begin{array}{r}-0.1136 \\
-2.26^{*}\end{array}$ & $\begin{array}{r}0.0677 \\
1.61\end{array}$ & $\begin{array}{l}0.0411 \\
3.73^{* *}\end{array}$ & $\begin{array}{r}-47978 \\
-16.45^{* *}\end{array}$ & $\begin{array}{r}-27084 \\
-6.72 * *\end{array}$ & $\begin{array}{r}7470 \\
2.26^{*}\end{array}$ & $\begin{array}{l}0.0370 \\
4.86^{* *}\end{array}$ & $\begin{array}{r}0.9630 \\
130.00^{* *}\end{array}$ \\
\hline CAD & $\begin{array}{r}195.82 \\
1.80\end{array}$ & $\begin{array}{l}-0.2266 \\
-4.40 * *\end{array}$ & $\begin{array}{l}0.1169 \\
4.00^{* *}\end{array}$ & $\begin{array}{r}0.0130 \\
1.34\end{array}$ & $\begin{array}{l}-239030 \\
-19.40^{* *}\end{array}$ & $\begin{array}{l}-82053 \\
-4.94 * *\end{array}$ & $\begin{array}{r}3049360 \\
0.28\end{array}$ & $\begin{array}{l}-0.0080 \\
-0.3124\end{array}$ & $\begin{array}{l}0.4263 \\
0.2049\end{array}$ \\
\hline GBP & $\begin{array}{r}17.46 \\
0.14\end{array}$ & $\begin{array}{l}-0.1682 \\
-2.96 * *\end{array}$ & $\begin{array}{l}0.0853 \\
2.50 * *\end{array}$ & $\begin{array}{r}-0.0025 \\
-0.17\end{array}$ & $\begin{array}{r}261780 \\
28.61^{* *}\end{array}$ & $\begin{array}{r}48176 \\
2.54^{* *}\end{array}$ & $\begin{array}{r}784519 \\
3.80 * *\end{array}$ & $\begin{array}{r}0.0292 \\
1.97^{*}\end{array}$ & $\begin{array}{r}0.8727 \\
29.68 * *\end{array}$ \\
\hline JPY & $\begin{array}{r}-44.36 \\
-0.2589\end{array}$ & $\begin{array}{r}-0.0363 \\
-0.70\end{array}$ & $\begin{array}{r}0.0150 \\
0.56\end{array}$ & $\begin{array}{c}-0.0265 \\
-2.24 *\end{array}$ & $\begin{array}{l}-163712 \\
-22.25^{* *}\end{array}$ & $\begin{array}{c}-30106 \\
-2.06^{*}\end{array}$ & $\begin{array}{r}5609848 \\
0.32\end{array}$ & $\begin{array}{r}0.0096 \\
0.29\end{array}$ & $\begin{array}{r}0.6048 \\
0.49\end{array}$ \\
\hline SFR & $\begin{array}{r}87.84 \\
0.63\end{array}$ & $\begin{array}{r}-0.0651 \\
-1.18\end{array}$ & $\begin{array}{r}0.0597 \\
1.85\end{array}$ & $\begin{array}{r}-0.0266 \\
-2.03^{*}\end{array}$ & $\begin{array}{l}-169763 \\
-24.42 * *\end{array}$ & $\begin{array}{c}-29319 \\
-2.15^{*}\end{array}$ & $\begin{array}{r}654479 \\
1.48\end{array}$ & $\begin{array}{r}0.0457 \\
1.94\end{array}$ & $\begin{array}{r}0.8834 \\
12.92^{* *}\end{array}$ \\
\hline Oil & $\begin{array}{r}57.23 \\
0.22\end{array}$ & $\begin{array}{l}-0.1632 \\
-3.37 * *\end{array}$ & $\begin{array}{r}-0.0089 \\
-0.54\end{array}$ & $\begin{array}{r}-0.0155 \\
-1.30\end{array}$ & $\begin{array}{r}50879 \\
11.17^{* *}\end{array}$ & $\begin{array}{r}27828 \\
5.24^{* *}\end{array}$ & $\begin{array}{r}19949483 \\
1.82\end{array}$ & $\begin{array}{r}-0.0302 \\
-1.47\end{array}$ & $\begin{array}{r}0.3779 \\
1.08\end{array}$ \\
\hline Gold & $\begin{array}{r}69.39 \\
0.44\end{array}$ & $\begin{array}{r}-0.1121 \\
-1.96\end{array}$ & $\begin{array}{r}0.0439 \\
2.27^{*}\end{array}$ & $\begin{array}{r}-0.0019 \\
-0.21\end{array}$ & $\begin{array}{r}2475 \\
0.17\end{array}$ & $\begin{array}{r}161713 \\
36.55 * *\end{array}$ & $\begin{array}{r}12364769 \\
7.20 * *\end{array}$ & $\begin{array}{l}0.1750 \\
4.59 * *\end{array}$ & $\begin{array}{r}-0.1219 \\
-0.91\end{array}$ \\
\hline S\&P & $\begin{array}{r}26.84 \\
0.17\end{array}$ & $\begin{array}{l}-0.1508 \\
-3.69 * *\end{array}$ & $\begin{array}{r}0.0806 \\
1.96\end{array}$ & $\begin{array}{l}0.0297 \\
5.96^{* *}\end{array}$ & $\begin{array}{r}27667 \\
3.83 * *\end{array}$ & $\begin{array}{r}7233 \\
0.78\end{array}$ & $\begin{array}{r}138205 \\
3.02 * *\end{array}$ & $\begin{array}{l}0.0398 \\
3.62 * *\end{array}$ & $\begin{array}{r}0.9607 \\
98.32^{* *}\end{array}$ \\
\hline Nikkei & $\begin{array}{r}11.69 \\
0.44\end{array}$ & $\begin{array}{r}-0.1028 \\
-1.74\end{array}$ & $\begin{array}{r}0.0038 \\
0.15\end{array}$ & $\begin{array}{l}0.0301 \\
8.80^{* *}\end{array}$ & $\begin{array}{r}1157 \\
1.54\end{array}$ & $\begin{array}{r}250.5 \\
0.30\end{array}$ & $\begin{array}{r}207410 \\
9.25 * *\end{array}$ & $\begin{array}{l}0.2796 \\
4.25^{* *}\end{array}$ & $\begin{array}{l}0.2409 \\
3.16^{* *}\end{array}$ \\
\hline
\end{tabular}

** $(*)$ denotes significance at the one (five) percent level. 
TABLE 17. HERDING IN FIRST DIFFERENCE OF NUMBER OF CONTRACTS OF NET SMALL TRADERS: GJR(1,1)

QMLE for the GJR(1,1) model of the first difference of the number of contracts held by net small speculators (dNETSML). dNETLRGE represents the first difference of the number of net large speculation contracts, dOI is the first difference of total futures market open interest, and SPOTRET denotes spot market returns. The sample is 520 observations from 6 October 1992 to 10 October 2002.

\begin{tabular}{|c|c|c|c|c|c|c|c|c|c|c|}
\hline Market & $C$ & $\begin{array}{c}d N E T \\
S M L \\
(-1) \\
\end{array}$ & $\begin{array}{c}\text { dNET } \\
\text { LRGE } \\
(-1) \\
\end{array}$ & $d O I$ & $\begin{array}{c}\text { SPOT } \\
R E T\end{array}$ & $\begin{array}{c}\text { SPOT } \\
R E T \\
(-1) \\
\end{array}$ & $\omega$ & $\alpha$ & $\beta$ & $\gamma$ \\
\hline AUD & $\begin{array}{r}59.60 \\
1.34\end{array}$ & $\begin{array}{r}-0.1120 \\
-2.38 *\end{array}$ & $\begin{array}{r}0.0728 \\
1.78\end{array}$ & $\begin{array}{l}0.0407 \\
3.34 * *\end{array}$ & $\begin{array}{r}-48998 \\
-17.51^{* *}\end{array}$ & $\begin{array}{r}-26708 \\
-6.84 * *\end{array}$ & $\begin{array}{r}5827 \\
1.94\end{array}$ & $\begin{array}{r}0.0130 \\
1.26\end{array}$ & $\begin{array}{r}0.9675 \\
143.5^{* *}\end{array}$ & $\begin{array}{r}0.0449 \\
2.43^{*}\end{array}$ \\
\hline CAD & $\begin{array}{r}214.35 \\
1.95\end{array}$ & $\begin{array}{l}-0.2209 \\
-4.34 * *\end{array}$ & $\begin{array}{l}0.1085 \\
3.80 * *\end{array}$ & $\begin{array}{r}0.0134 \\
1.37\end{array}$ & $\begin{array}{l}-241246 \\
-19.96 * *\end{array}$ & $\begin{array}{r}-84172 \\
-5.19 * *\end{array}$ & $\begin{array}{r}3396942 \\
0.67\end{array}$ & $\begin{array}{r}0.0187 \\
0.45\end{array}$ & $\begin{array}{r}0.3630 \\
0.38\end{array}$ & $\begin{array}{r}-0.0569 \\
-1.03\end{array}$ \\
\hline GBP & $\begin{array}{r}39.36 \\
0.31^{* *}\end{array}$ & $\begin{array}{l}-0.1721 \\
-2.97 * *\end{array}$ & $\begin{array}{l}0.0867 \\
2.54 * *\end{array}$ & $\begin{array}{r}-0.0077 \\
-0.51\end{array}$ & $\begin{array}{r}263338 \\
28.05^{* *}\end{array}$ & $\begin{array}{r}51593 \\
2.66^{* *}\end{array}$ & $\begin{array}{c}901724 \\
3.55^{* *}\end{array}$ & $\begin{array}{r}0.0591 \\
2.24^{*}\end{array}$ & $\begin{array}{r}0.8484 \\
22.59 * *\end{array}$ & $\begin{array}{r}-0.0386 \\
-1.42\end{array}$ \\
\hline JPY & $\begin{array}{r}-39.88 \\
-0.23\end{array}$ & $\begin{array}{r}-0.0369 \\
-0.71\end{array}$ & $\begin{array}{r}0.0140 \\
0.52\end{array}$ & $\begin{array}{r}-0.0263 \\
-2.22 *\end{array}$ & $\begin{array}{l}-164062 \\
-21.66^{* *}\end{array}$ & $\begin{array}{l}-30630 \\
-2.04^{*}\end{array}$ & $\begin{array}{r}8836424 \\
0.40\end{array}$ & $\begin{array}{r}0.0082 \\
0.22\end{array}$ & $\begin{array}{r}0.3785 \\
0.24\end{array}$ & $\begin{array}{r}0.0111 \\
0.16\end{array}$ \\
\hline SFR & $\begin{array}{r}109.54 \\
0.75\end{array}$ & $\begin{array}{r}-0.0683 \\
-1.25\end{array}$ & $\begin{array}{r}0.0584 \\
1.83\end{array}$ & $\begin{array}{l}-0.0310 \\
-2.37 * *\end{array}$ & $\begin{array}{l}-167445 \\
-22.97 * *\end{array}$ & $\begin{array}{l}-31334 \\
-2.43 * *\end{array}$ & $\begin{array}{r}681394 \\
1.60\end{array}$ & $\begin{array}{l}0.0792 \\
2.47 * *\end{array}$ & $\begin{array}{r}0.8782 \\
13.67^{* *}\end{array}$ & $\begin{array}{r}-0.0604 \\
-1.85\end{array}$ \\
\hline Oil & 58.18 & $\begin{array}{l}-0.1622 \\
-3.40 * *\end{array}$ & $\begin{array}{r}-0.0079 \\
-0.48\end{array}$ & -0.0150 & $\begin{array}{r}51049 \\
11.19^{* *}\end{array}$ & $\begin{array}{l}27833 \\
5.20^{* *}\end{array}$ & $\begin{array}{r}1994947 \\
7 \\
1.86\end{array}$ & -0.0474 & 0.3867 & 0.0175 \\
\hline Gold & $\begin{array}{r}15.54 \\
0.09\end{array}$ & $\begin{array}{r}-0.0906 \\
-1.75\end{array}$ & $\begin{array}{r}0.0460 \\
2.37^{*}\end{array}$ & $\begin{array}{r}0.0037 \\
0.40\end{array}$ & $\begin{array}{r}1486 \\
0.09\end{array}$ & $\begin{array}{r}168283 \\
38.22^{* *}\end{array}$ & $\begin{array}{r}7528636 \\
3.41^{* *}\end{array}$ & $\begin{array}{r}-0.0018 \\
-0.06\end{array}$ & $\begin{array}{r}0.3154 \\
1.70\end{array}$ & $\begin{array}{l}0.2079 \\
3.56^{* *}\end{array}$ \\
\hline S\&P & $\begin{array}{r}81.93 \\
0.49\end{array}$ & $\begin{array}{l}-0.1579 \\
-3.95 * *\end{array}$ & $\begin{array}{r}0.0876 \\
2.10^{*}\end{array}$ & $\begin{array}{l}0.0280 \\
5.56 * *\end{array}$ & $\begin{array}{r}26056 \\
3.37 * *\end{array}$ & $\begin{array}{r}6653 \\
0.71\end{array}$ & $\begin{array}{c}125058 \\
3.01^{* *}\end{array}$ & $\begin{array}{l}0.0503 \\
2.75 * *\end{array}$ & $\begin{array}{r}0.9648 \\
101.5^{* *}\end{array}$ & $\begin{array}{r}-0.0273 \\
-1.11\end{array}$ \\
\hline Nikkei & $\begin{array}{l}-4.14 \\
-0.15\end{array}$ & $\begin{array}{c}-0.1262 \\
-1.99 *\end{array}$ & $\begin{array}{r}-0.0046 \\
-0.18\end{array}$ & $\begin{array}{r}0.0305 \\
8.94\end{array}$ & $\begin{array}{r}1385 \\
1.94\end{array}$ & $\begin{array}{r}450 \\
0.58\end{array}$ & $\begin{array}{r}203738 \\
8.74\end{array}$ & $\begin{array}{r}0.1270 \\
2.06 *\end{array}$ & $\begin{array}{l}0.2359 \\
3.12 * *\end{array}$ & $\begin{array}{r}0.3751 \\
2.51^{*}\end{array}$ \\
\hline
\end{tabular}

** $(*)$ denotes significance at the one (five) percent level. 
The model for SFR, for which there was some evidence against no ARCH effects in Tables 11 and 12, seems to display statistically significant ARCH effects in most specifications in Tables 13-17. In levels, Tables 14 and 15 indicate that asymmetry in volatility exists for AUD, CAD, GBP S\&P and Nikkei. When the model is estimated in first differences, Tables 17 and 18 show that the conditional variance of small traders is asymmetric for AUD, oil, gold and Nikkei, with marginal evidence of asymmetry for SFR small traders.

The existence of asymmetry provides insights into how small traders trade. When small traders sell more than expected, there is an increase in the conditional variance of small traders. If small traders sell when markets are falling, they may be more uncertain about their decisions, thereby leading to increased volatility. As small traders comprise a large segment of the market, such a finding has consequences for futures market regulations, and raises issues as to how small traders behave in falling, as opposed to rising, markets. Size limits and price restrictions in falling markets may be justified if the uncertainty of small traders is increased, thereby creating greater volatility in market prices.

\subsection{Impacts on Volatility}

The empirical results provide evidence of herding among small trader positions in some markets. However, the existence of herding does not necessarily imply that such behaviour is destabilising. Nofsinger and Sias (1999) have argued that herding among institutions may result in prices moving toward equilibrium faster than without herding. Whether or not small traders have an impact on market volatility is highly significant for policymakers and market regulators. If it can be shown that small traders affect price volatility adversely, measures that may dampen their influence upon prices should be investigated. Conversely, if small traders do not affect market volatility, in spite of herding, they should not be the target of policy that is designed to influence their impact on price variability. While some may argue that the existence of arbitrageurs and fundamentals-based traders will prevent noise traders from pushing asset prices away from fundamental values for prolonged periods, theoretical models, such as De Long et al. (1990b), show that the existence of noise traders creates noise or small trader risk that may prevent rational traders from eliminating subsequent price discrepancies.

In order to test the impact of small traders on price volatility, Hong's (2001) unidirectional 
TABLE 18. HERDING IN FIRST DIFFERENCE OF NUMBER OF CONTRACTS OF NET SMALL TRADERS: EGARCH(1,1)

QMLE for the EGARCH(1,1) model of the first difference of the number of contracts held by net small speculators (dNETSML). dNETLRGE represents the first difference of the number of net large speculation contracts, dOI is the first difference of total futures market open interest, and SPOTRET denotes spot market returns. The sample is 520 observations from 6 October 1992 to 10 October 2002.

\begin{tabular}{|c|c|c|c|c|c|c|c|c|c|c|}
\hline Market & $C$ & $\begin{array}{c}d N E T \\
S M L \\
(-1) \\
\end{array}$ & $\begin{array}{c}d N E T \\
L R G E \\
(-1) \\
\end{array}$ & $d O I$ & $\begin{array}{c}\text { SPOT } \\
R E T\end{array}$ & $\begin{array}{c}\text { SPOT } \\
R E T \\
(-1) \\
\end{array}$ & $\omega$ & $\alpha$ & $\gamma$ & $\beta$ \\
\hline AUD & $\begin{array}{r}37.99 \\
0.82\end{array}$ & $\begin{array}{r}-0.1154 \\
-2.45^{*}\end{array}$ & $\begin{array}{r}0.0541 \\
1.29\end{array}$ & $\begin{array}{l}0.0350 \\
2.90 * *\end{array}$ & $\begin{array}{r}-58297 \\
-19.24 * *\end{array}$ & $\begin{array}{l}-32200 \\
-8.62 * *\end{array}$ & $\begin{array}{r}-0.0035 \\
-0.08\end{array}$ & $\begin{array}{l}0.0661 \\
4.13^{* *}\end{array}$ & $\begin{array}{r}-0.0258 \\
-1.70\end{array}$ & $\begin{array}{r}0.9971 \\
366.48 * *\end{array}$ \\
\hline CAD & $\begin{array}{r}206.67 \\
1.91\end{array}$ & $\begin{array}{l}-0.2198 \\
-4.72 * *\end{array}$ & $\begin{array}{l}0.1113 \\
3.96^{* *}\end{array}$ & $\begin{array}{r}0.0112 \\
1.13\end{array}$ & $\begin{array}{c}-239049 \\
-19.76 * *\end{array}$ & $\begin{array}{c}-82304 \\
-5.41^{* *}\end{array}$ & $\begin{array}{l}6.21 \\
1.13\end{array}$ & $\begin{array}{r}-0.0958 \\
-1.22\end{array}$ & $\begin{array}{r}0.0397 \\
0.71\end{array}$ & $\begin{array}{r}0.6035 \\
1.70\end{array}$ \\
\hline GBP & $\begin{array}{r}38.52 \\
0.30\end{array}$ & $\begin{array}{l}-0.1567 \\
-3.25^{* *}\end{array}$ & $\begin{array}{l}0.0883 \\
2.79 * *\end{array}$ & $\begin{array}{r}0.0010 \\
0.07\end{array}$ & $\begin{array}{r}243378 \\
27.61^{* *}\end{array}$ & $\begin{array}{r}37260 \\
2.06^{*}\end{array}$ & $\begin{array}{l}0.3922 \\
5.11^{* *}\end{array}$ & $\begin{array}{r}0.0087 \\
0.39\end{array}$ & $\begin{array}{l}0.0112 \\
0.8337\end{array}$ & $\begin{array}{r}0.9748 \\
223.24^{* *}\end{array}$ \\
\hline JPY & $\begin{array}{r}-18.78 \\
-0.11\end{array}$ & $\begin{array}{r}-0.0327 \\
-0.63\end{array}$ & $\begin{array}{r}0.0062 \\
0.23\end{array}$ & $\begin{array}{r}-0.0252 \\
-2.15^{*}\end{array}$ & $\begin{array}{c}-165437 \\
-21.30 * *\end{array}$ & $\begin{array}{l}-32001 \\
-2.06 *\end{array}$ & $\begin{array}{l}19.54 \\
1.99 *\end{array}$ & $\begin{array}{r}0.0937 \\
0.99\end{array}$ & $\begin{array}{r}-0.0789 \\
-1.37\end{array}$ & $\begin{array}{r}-0.1897 \\
-0.32\end{array}$ \\
\hline SFR & $\begin{array}{r}69.09 \\
0.49\end{array}$ & $\begin{array}{r}-0.0801 \\
-1.55\end{array}$ & $\begin{array}{r}0.0503 \\
1.64\end{array}$ & $\begin{array}{r}-0.0209 \\
-1.59\end{array}$ & $\begin{array}{l}-180852 \\
-29.11^{* *}\end{array}$ & $\begin{array}{c}-33481 \\
-2.55 *\end{array}$ & $\begin{array}{l}21.52 \\
2.03^{*}\end{array}$ & $\begin{array}{r}0.0186 \\
0.25\end{array}$ & $\begin{array}{r}-0.0419 \\
-0.81\end{array}$ & $\begin{array}{r}-0.3447 \\
-0.52\end{array}$ \\
\hline Oil & $\begin{array}{r}154.37 \\
0.60\end{array}$ & $\begin{array}{l}-0.1583 \\
-4.14^{* *}\end{array}$ & $\begin{array}{r}-0.0073 \\
-0.47\end{array}$ & $\begin{array}{r}-0.0231 \\
-1.96\end{array}$ & $\begin{array}{r}49746 \\
11.16^{* *}\end{array}$ & $\begin{array}{r}2840 \\
5.65 * *\end{array}$ & $\begin{array}{r}11.86 \\
3.28 * *\end{array}$ & $\begin{array}{r}-0.1908 \\
-2.06 *\end{array}$ & $\begin{array}{l}0.1787 \\
3.46 * *\end{array}$ & $\begin{array}{r}0.3193 \\
1.53\end{array}$ \\
\hline Gold & $\begin{array}{r}44.18 \\
0.28\end{array}$ & $\begin{array}{r}-0.0842 \\
-1.61\end{array}$ & $\begin{array}{l}0.0503 \\
2.68^{* *}\end{array}$ & $\begin{array}{r}0.0028 \\
0.34\end{array}$ & $\begin{array}{r}-8789 \\
-0.60\end{array}$ & $\begin{array}{r}159578 \\
36.00 *\end{array}$ & $\begin{array}{r}2.82 \\
2.92 * *\end{array}$ & $\begin{array}{l}0.2519 \\
4.48 * *\end{array}$ & $\begin{array}{r}-0.0792 \\
-2.03 *\end{array}$ & $\begin{array}{r}0.8164 \\
13.55^{* *}\end{array}$ \\
\hline S\&P & $\begin{array}{r}210.07 \\
1.33\end{array}$ & $\begin{array}{l}-0.1594 \\
-3.92 * *\end{array}$ & $\begin{array}{r}0.0754 \\
1.94\end{array}$ & $\begin{array}{l}0.0295 \\
5.88 * *\end{array}$ & $\begin{array}{r}23114 \\
2.90^{* *}\end{array}$ & $\begin{array}{r}4203 \\
0.46\end{array}$ & $\begin{array}{r}0.0150 \\
0.25\end{array}$ & $\begin{array}{l}0.1164 \\
4.49 * *\end{array}$ & $\begin{array}{r}0.0276 \\
1.00\end{array}$ & $\begin{array}{r}0.9945 \\
313.49 * *\end{array}$ \\
\hline Nikkei & $\begin{array}{l}-4.16 \\
-0.16\end{array}$ & $\begin{array}{r}-0.1421 \\
-2.47^{*}\end{array}$ & $\begin{array}{r}-0.0036 \\
-0.15\end{array}$ & $\begin{array}{l}0.0274 \\
9.00 * *\end{array}$ & $\begin{array}{r}1605 \\
2.41^{*}\end{array}$ & $\begin{array}{r}392 \\
0.51\end{array}$ & $\begin{array}{r}4.81 \\
5.89 * *\end{array}$ & $\begin{array}{l}0.4324 \\
6.71 * *\end{array}$ & $\begin{array}{l}-0.1513 \\
-2.77^{* *}\end{array}$ & $\begin{array}{l}0.6023 \\
9.25 * *\end{array}$ \\
\hline
\end{tabular}

** $(*)$ denotes significance at the one (five) percent level. 
test of causality-in-variance is conducted. The test statistic, which is asymptotically distributed as $\mathrm{N}(0,1)$ under the null hypothesis of no causality, is based on two conditionally heteroskedastic series, possibly with infinite unconditional variance, and examines whether the conditional variance of one series spills over into the other. As many of the small trader series exhibit conditionally heteroskedastic errors, this test is likely to provide insight into how small traders affect market volatility. If the volatility of small trader positions changes over time, this could reflect differing degrees of uncertainty or information releases. Moreover, if the volatility of small traders spills over into price variability, this would provide evidence that small traders destabilise markets.

The statistic tests whether the estimated correlation coefficient, $\hat{\rho}_{u v}$, between two standardized residuals, $u$ and $v$, is significantly different from zero, and is given by

$$
T \sum_{j=1}^{T-1} k^{2}(j / M) \hat{\rho}_{u v}^{2}(j)
$$

Hong (2001) allows the test procedure to attribute different weights to each lag through a weighting function, $\mathrm{k}($.$) , which increases the power of the test and recognises that past$ information is less important than more recent information. Two weighting kernels are used, namely Bartlett and Daniell, which are defined, respectively, as

$$
k(z)= \begin{cases}1-|z|, & |z| \leq 1 \\ 0, & \text { otherwise }\end{cases}
$$

and

$$
k(z)=\sin (\pi z) / \pi z, \quad-\infty<\mathrm{z}<\infty .
$$

For these kernels, all T-1 lags are included, but with declining weights.

The results for the Hong test using the Daniell kernel, for which $M$ was chosen as 2, 5, 10 and 20, are given in Table 19. ${ }^{4}$ Spot returns were estimated using the AR(1)-GARCH(1,1) model,

\footnotetext{
${ }^{4}$ The Bartlett kernel results led to quantitatively similar results, and are available from the authors on request.
} 
while the conditional mean for small traders is given in equation (1) with GARCH(1,1) errors. The results in Table 19, which are robust to the choice of weighting kernel, suggest that the conditional volatility displayed by small traders does not significantly affect the conditional volatility in spot returns, with the exception of Nikkei when $M$ is high. A possible explanation for the significance of the test statistic for higher-order lags is outlined in Hong (2001). Specifically, longer lags provide greater power of the test where each lagged correlation coefficient is only marginally significant, but where the lags are jointly significant. For this reason, it does not seem that small traders destabilise spot prices, in general, despite the tendency for herding in some markets.

\section{Conclusion}

Using data on the positions of futures traders across nine different financial commodities, the empirical results suggest the presence of herding behaviour among small traders across some markets. These results were found to be robust to asymmetric time-varying conditional volatility effects in the model of small traders. The currencies, commodities and indices analysed are well developed markets with a high degree of transparency. According to Bikhchandani et al. (1992), herding is more likely to occur when agents are less confident of their own information, which is more likely be found in less-developed markets. Thus, an analysis of emerging markets, data permitting, would provide an interesting avenue for future research. $^{5}$

Furthermore, given the extent to which macro hedge funds have been blamed for the Asian economic and financial crises (see de Brouwer (2001)), it would be interesting to examine whether potential sub-categories of large speculators, such as hedge funds and proprietary trading desks, exert an influence on other market participants, such as small traders. de Brouwer (2001, p. 165) notes that many large hedge funds realize that small traders react to the trades of hedge funds, and use this information. Decomposing large speculators into hedge funds, which are often viewed as market leaders, and testing the extent to which they influence small traders, is also a fruitful avenue for future research.

\footnotetext{
${ }^{5}$ Recall that Chang et al. (2000) found evidence of herding in South Korea and Taiwan, where herding was measured as changes in the average dispersion of stocks around market returns in periods of market calm versus extreme conditions. No data on small traders were used.
} 
TABLE 19 - HONG TEST OF CAUSALITY IN VARIANCE FROM SMALL TRADERS TO SPOT RETURNS (Daniell Kernel)

\begin{tabular}{l|llll}
\hline Market & $M=2$ & $M=5$ & $M=10$ & $M=20$ \\
\hline AUD & -0.706 & -0.179 & -0.122 & -0.420 \\
CAD & 1.009 & 0.405 & 1.488 & 1.427 \\
GBP & -0.538 & 0.555 & 0.337 & -1.128 \\
JPY & -0.702 & -0.296 & 1.510 & -0.133 \\
SFR & -0.682 & -0.719 & -1.073 & 1.331 \\
Oil & -0.636 & -0.676 & -0.828 & -0.029 \\
Gold & -0.707 & -0.740 & -1.180 & -1.695 \\
S\&P & 0.507 & 0.026 & -0.519 & -0.884 \\
Nikkei & -0.650 & -0.216 & $3.045^{* *}$ & $2.128^{*}$ \\
\hline
\end{tabular}

** $(*)$ denotes significance at the one (five) percent level. Critical values are obtained from the upper tail of the $\mathrm{N}(0,1)$ distribution. 
There are far-reaching economic implications of the existence of herding. The possibility of herding can lead to multiple equilibria, causing asset prices to deviate for prolonged periods from fundamentals, and diminish the effectiveness of such markets in channelling scarce capital. Moreover, in markets in which the null hypothesis of no herding is rejected, the volatility exhibited is likely to be higher than if agents did not herd because herding leads to a greater concentration of agents on one side of the market. The mimicry of small traders would either add momentum to price changes in these markets, or cause prices to overshoot the price that would be determined in the absence of herding. Fluctuations in prices are, therefore, likely to be magnified by herding, resulting in more volatile and less informative prices. Participants in international trade and investment would be exposed to greater foreign exchange risk, and exchange rate movements would be rendered less informative by the greater volatility arising from the herding behaviour of small traders.

The results of this paper contribute to the debate on the desirability of the existence of noise traders in financial markets. Noise traders perform the critical function of providing liquidity to markets and enabling informed traders to transact, by which information is impounded into financial market prices. A perverse result of the homogeneous agent perfect information trading models is that no trading occurs because agents have identical expectations, and hence have no reason to trade. As noise traders facilitate the smooth operation of financial markets, it is difficult to argue that noise trading should be limited by measures such as transaction taxes, or if society would benefit from the limitation of noise trading. Schwert and Seguin (1993) state that the effect on market volatility of limiting noise trading is ambiguous. While herding noise traders may exacerbate price changes, lower market liquidity may result in more rapid price changes as it implies that a market is less able to absorb large trades. Furthermore, prices may become less informative, thereby resulting in financial markets that are less effective in allocating scare capital. 


\section{References}

Asch, S. (1952), Social Psychology, Englewood Cliffs, New Jersey, Prentice-Hall.

Admati A. and P. Pfleiderer (1997), 'Does It All Add Up? Benchmarks and the Compensation of Active Portfolio Managers’, Journal of Business, 70, 323-350.

Avery, C. and P. Zemsky (1998), 'Multidimensional Uncertainty and Herd Behavior in Financial Markets’, American Economic Review, 88, 724-748.

Banerjee, A. (1992), 'A Simple Model of Herd Behavior', Quarterly Journal of Economics, 107, 797-818.

Becker, G.S. (1991), 'A Note on Restaurant Pricing and Other Example of Social Influence on Price’, Journal of Political Economy, 99, 1109-1116.

Bessembinder, H. and P.J. Seguin (1992), 'Futures-Trading Activity and Stock Price Volatility', Journal of Finance, 47, 2015-2034.

Bikhchandani, S., D. Hirshleifer and I. Welch (1992) 'A Theory of Fads, Fashion, Custom and Cultural Change as Informational Cascades', Journal of Political Economy, 100, 9921026.

Bikhchandani, S., D. Hirshleifer and I. Welch (1998) 'Learning from the Behavior of Others: Conformity, Fads and Informational Cascades', Journal of Economic Perspectives, 12, 151170.

Bikhchandani, S. and S. Sharma, (2000) 'Herd Behavior in Financial Markets: A Review', IMF Working Paper, WP/00/48.

Black, F. (1986), 'Noise’, Journal of Finance, 41, 529-543.

Bollerslev, T. (1986), 'Generalized Autoregressive Conditional Heteroskedasticity', Journal of Econometrics, 31, 307-327.

Bollerslev, T. and J.M. Wooldridge (1991), 'Quasi Maximum Likelihood Estimation and Inference in Dynamic Models with Time-Varying Covariances', Econometric Reviews, 11, 143-172.

Bollerslev, T., R.Y. Chou and K.F. Kroner (1992), 'ARCH Modeling in Finance: A Review of the Theory and Empirical Evidence', Journal of Econometrics, 52, 5-59.

Bollerslev, T., R.F. Engle and D.B. Nelson (1994), 'ARCH Models', in R.F. Engle and D.L. McFadden (eds.), Handbook of Econometrics, Vol. 4, Amsterdam, Elsevier, 2959-3038.

Brunnermeier, M.K. (2001), Asset Pricing under Asymmetric Information: Bubbles, Crashes, Technical Analysis and Herding, Oxford University Press, New York. 
Caporin, M. and M. McAleer (2012), 'Model selection and testing of conditional and stochastic volatility models', in L. Bauwens, C. Hafner and S. Laurent (eds.), Handbook on Financial Engineering and Econometrics: Volatility Models and Their Applications, Wiley, New York, pp. 199-222.

Chang, E.C., J.W. Cheng and A. Khorana (2000) 'An Examination of Herd Behavior in Equity Markets: An International Perspective’, Journal of Banking and Finance, 24, 16511679.

Christie, W.G. and R.D. Huang (1995), 'Following the Pied Piper: Do Individual Returns Herd Around the Market?', Financial Analysts Journal, 51, 31-37.

Choe, H., B. Kho and R.M. Stulz (1999) 'Do Foreign Investors Destabilize Stock Markets?', Journal of Financial Economics, 54, 227-264.

de Brouwer, G. (2001), Hedge Funds in Emerging Markets, Cambridge University Press, Cambridge.

De Long, J.B., A. Shleifer, L.H. Summers and R.J. Waldmann, (1990a), 'Positive Feedback Investment Strategies and Destabilizing Rational Speculation’, Journal of Finance, 45, 379395.

De Long, J.B., A. Shleifer, L.H. Summers and R.J. Waldmann (1990b), 'Noise Trader Risk in Financial Markets', Journal of Political Economy, 98, 703-738.

Devenow, A. and I. Welch (1996) 'Rational Herding in Financial Economics', European Economic Review, 40, 603-615.

Engle, R.F. (1982), 'Autoregressive Conditional Heteroskedasticity with Estimates of the Variance of United Kingdom Inflation’, Econometrica, 50, 987-1007.

Froot, K.A., D.S. Scharfstein and J.C. Stein (1992), 'Herd on the Street: Informational Inefficiencies in a Market with Short-Term Speculation', Journal of Finance, 47, 1461-1484.

Glosten, L., R. Jagannathan and D. Runkle (1993), 'On the Relation Between the Expected Value and the Volatility of Nominal Excess Return on Stocks', Journal of Finance, 48, 17701801.

Graham, J.R. (1999), 'Herding Among Investment Newsletters: Theory and Evidence', Journal of Finance, 54, 237-268.

Grinblatt, M., S. Titman and R. Wermers (1995), 'Momentum Investment Strategies, Portfolio Performance and Herding: A Study of Mutual Fund Behavior', American Economic Review, 85, 1088-1105.

Hong, Y. (2001), “A Test for Volatility Spillover with Application to Exchange Rates', Journal of Econometrics, 103, 183-224.

Keynes, J.M. (1936), General Theory of Employment, Interest and Money, Macmillan, London. 
Kodres, L. and M. Pritsker (1996), 'Directionally-Similar Position Taking and Herding by Large Futures Markets Participants', in Risk Measurement and Systematic Risk: Proceedings of a Joint Central Bank Research Conference, Board of Governors of the Federal Reserve, 221-272.

Kyle, A.S. (1985), 'Continuous Auctions and Insider Trading', Econometrica, 53, 1315-1336.

Lakonishok, J., A. Shleifer and R.W. Vishny (1992), 'The Impact of Institutional Trading on Stock Prices’, Journal of Financial Economics, 32, 23-43.

Li, W.K., S. Ling and M. McAleer (2002), 'Recent Theoretical Results for Time Series Models with GARCH Errors', Journal of Economic Surveys, 245-270. Reprinted in M. McAleer and L. Oxley (eds.), Contributions to Financial Econometrics: Theoretical and Practical Issues, Blackwell, Oxford, 2002, pp. 9-33.

McAleer, M. (2005), 'Automated inference and learning in modeling financial volatility', Econometric Theory, 21, 232-261.

McAleer, M., F. Chan and D. Marinova (2007), 'An Econometric Analysis of Asymmetric Volatility: Theory and Application to Patents’, Journal of Econometrics, 139, 259-284.

Neftci, S.N. (1996), An Introduction to the Mathematics of Financial Derivatives, Academic Press, San Diego.

Nelson, D.B. (1990), 'Conditional Heteroskedasticity in Asset Returns: A New Approach', Econometrica, 59, 347-370.

Newey, W. and K. West (1987), 'A Simple Positive Semi-definite, Heteroskedasticity and Autocorrelation Consistent Covariance Matrix’, Econometrica, 55, 703-708.

Nofsinger, J.R., and R.W. Sias (1999), 'Herding and Feedback Trading by Institutional and Individual Investors’, Journal of Finance, 54, 2263-2295.

Roll, R., (1992), 'A Mean-Variance Analysis of Tracking Error', Journal of Portfolio Management, 18, 465-479.

Scharfstein, D. and J. Stein (1990), 'Herd Behavior and Investment', American Economic Review, 80, 465-479.

Schwert, G.W. and P.J. Seguin, (1993), 'Securities Transaction Taxes: An Overview of Costs, Benefits and Unresolved Questions’, Financial Analysts Journal, 49, 27-35.

Shalen, C.T. (1993), 'Volume, Volatility, and the Dispersion of Beliefs', Review of Financial Studies, 6, 405-434.

Shephard, N. (1996), 'Statistical Aspects of ARCH and Stochastic Volatility', in O.E. Barndoff-Nielsen, D.R. Cox and D.V. Hinkley (eds.), Statistical Models in Econometrics, Finance and Other Fields, Chapman \& Hall, London, pp. 1-67. 
Shiller, R.J. (1995), 'Rhetoric and Economic Behavior: Conversation, Information and Herd Behavior’, American Economic Review, 85, 181-185.

Welch, I. (1992), 'Sequential Sales, Learning and Cascades', Journal of Finance, 47, 695732.

Welch, I. (2000), 'Herding Among Security Analysts', Journal of Financial Economics, 58, 369-396.

Wermers, R. (1999), 'Mutual Fund Herding and the Impact on Stock Prices', Journal of Finance, 54, 581-622. 